\title{
Does Application of 'phosphogypsum Organic' to a Sandy BRIS Soil Has an Impact on Soil-plants-water Systems?
}

Mohamed M. Hanafi ( $\sim$ mmhanafi@upm.edu.my )

Universiti Putra Malaysia https://orcid.org/0000-0003-1898-6819

Parisa Azizi

UNIVERSITI PUTRA MALAYISA

Abdul Rahim Sahibin

Universiti Malaysia Sabah

Idris Wan Mohd Razi

Universiti Kebangsaan Malaysia

Ismail Aznan Fazli

Universiti Kebangsaan Malaysia

\section{Research}

Keywords: Sandy BRIS soil, Phosphogypsum organic, Heavy metals, Pollution indices, Radiological hazard index

Posted Date: October 27th, 2020

DOI: https://doi.org/10.21203/rs.3.rs-96178/v1

License: (c) (i) This work is licensed under a Creative Commons Attribution 4.0 International License. Read Full License 


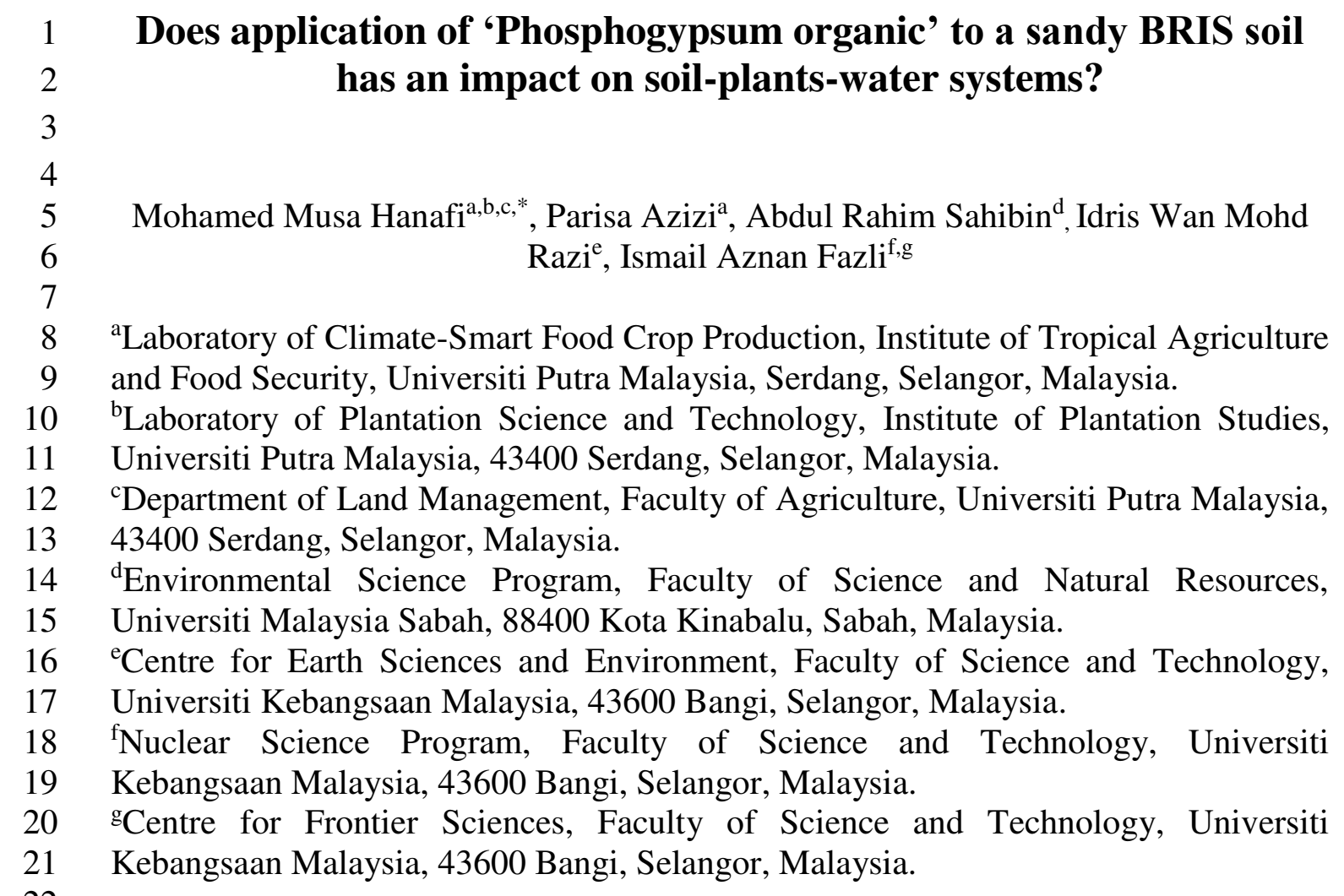

12 'Department of Land Management, Faculty of Agriculture, Universiti Putra Malaysia, 1343400 Serdang, Selangor, Malaysia.

14 dEnvironmental Science Program, Faculty of Science and Natural Resources, 15 Universiti Malaysia Sabah, 88400 Kota Kinabalu, Sabah, Malaysia.

$16{ }^{\mathrm{e}}$ Centre for Earth Sciences and Environment, Faculty of Science and Technology, 17 Universiti Kebangsaan Malaysia, 43600 Bangi, Selangor, Malaysia.

$18{ }^{\mathrm{f}}$ Nuclear Science Program, Faculty of Science and Technology, Universiti 19 Kebangsaan Malaysia, 43600 Bangi, Selangor, Malaysia.

$20{ }^{\mathrm{g}}$ Centre for Frontier Sciences, Faculty of Science and Technology, Universiti 21 Kebangsaan Malaysia, 43600 Bangi, Selangor, Malaysia.

*Corresponding to: Mohamed Musa Hanafi, Department of Land Management,

26 Faculty of Agriculture, Universiti Putra Malaysia, 43400 Serdang, Selangor, 27 Malaysia. 


\begin{abstract}
39 Background: Predominant sandy, Beach Ridges Interspersed with Swales (BRIS)

40 soil is a problematical soil for agriculture. It requires structure and capacity

41 improvement due to its weak composition, low water retention capacity and high

42 leaching of nutrients. However, there are hopes to improve it using different fertilizers

43 in combination with organic matter. Phosphogypsum organic (PG organic) is an

44 agricultural soil conditioner formulated from industrial by-products and organic filler

45 material. This research was carried out to investigate the accumulated levels of heavy

46 metals and radionuclides in water, soil and plants between BRIS soil under PG

47 organic conditioner treatment and normal BRIS soil.
\end{abstract}

48 Results: The result revealed that the PG organic's particles are as similar to the 49 reported pattern for calcium sulfate hydrate through powder X-ray diffraction (XRD).

50 The heavy metals measured in the surface and borehole water, and soils were below 51 the target values for raw drinking water and in the Dutch list, respectively. The values 52 for biological accumulation coefficients, contamination factors, I-geo index and 53 pollution load index (PLI) showed that there was no accumulation of metals in grain, 54 no contamination and no pollution in the BRIS soil that received from the PG organic. 55 Natural radioactivity concentrations, ${ }^{226} \mathrm{Ra}\left({ }^{238} \mathrm{U}\right.$ series), ${ }^{228} \mathrm{Ra}\left({ }^{232} \mathrm{Th}\right.$ series), and ${ }^{40} \mathrm{~K}$ 56 in the collected samples were also measured. Naturally occurring radionuclide 57 concentrations, such as ${ }^{226} \mathrm{Ra},{ }^{228} \mathrm{Ra}$, and ${ }^{40} \mathrm{~K}$, in soil and plant tissue were found to be 58 lower than the average value reported by several earlier studies in Malaysia. There 59 was no leaching of natural occurring radionuclides to the groundwater, nor was there 60 discharge to the nearest river. The calculated radium equivalent $\left(\mathrm{Ra}_{\mathrm{eq}}\right)$ in soil for this 61 study was lower than the recommended value of $370 \mathrm{~Bq} / \mathrm{kg}$ soil.

62 Conclusion: Therefore, the application of PG organic to the studied soil had no 63 impact on the soil, plants and water and suitable as a soil conditioner in BRIS soil.

64 Keywords: Sandy BRIS soil, Phosphogypsum organic, Heavy metals, Pollution 65 indices, Radiological hazard index.

\title{
66 Background
}

67 Phosphogypsum organic (PG organic) contains neutralization underflow (NUF)

68 residue, water leached purification (WLP) residue from rare-earth elements

69 processing, and organic filler material in a ratio of 2:1:7. The NUF residue is a solvent

70 extraction and product finishing raffinate neutralized with lime. It is also known as

$71 \mathrm{Mg}$ rich synthetic gypsum (MRSG) as it is primarily gypsum [1]. Although NUF is

72 classified by the Department of Environment (DOE), Malaysia as SW205, it is not a

73 hazardous material for use and does not negatively impact the environment [2-3].

74 Meanwhile, WLP residue is produced from the precipitation of post leaching liquor 
75 with $\mathrm{MgO}$. It is primarily iron phosphate, with minor iron hydroxide, aluminium

76 hydroxide and gypsum and contains thorium at activity concentration of about $6 \mathrm{~Bq} / \mathrm{g}$.

77 It is classified as radioactive material by the Atomic Energy and Licensing Board

78 (AELB), Malaysia and defined by the International Atomic Energy Agency (IAEA) as

79 a very low level radioactive waste [4].

80 PG organic contains no significant amounts of radionuclides other than naturally 81 occurring radionuclides (each radionuclide in the $\mathrm{U}$ or Th decay chain is $<1 \mathrm{~Bq} / \mathrm{g}$ or

$82 \mathrm{~K}-40<10 \mathrm{~Bq} / \mathrm{g}$ ), ultimately is not a radioactive material as reported by Malaysia

83 Nuclear Agency (MNA) and approved by the AELB [5]. Furthermore, combination of

84 WLP and NUF has potential to improve soil nutrients $\left(\mathrm{Ca}^{2+}, \mathrm{SO}_{4}{ }^{2-}, \mathrm{Mg}^{2+}, \mathrm{PO}_{4}{ }^{3-}, \mathrm{PO}_{4}{ }^{2-}\right.$

85 and $\left.\mathrm{SO}_{4}{ }^{2-}\right)$, reduce soil toxicity $\left(\mathrm{SO}_{4}{ }^{2-}\right.$ reduces $\mathrm{Al}$ toxicity), change soil mechanics

$86\left(\mathrm{Ca}^{2+}\right.$ promotes flocculation in soil hardening process) and act as liming agent to

87 increase $\mathrm{pH}$ of acidic soil for nutrient uptake.

88 The Beach Ridges Interspersed with Swales (BRIS) soil with more than $90 \%$ of sand

89 composition is a problematical soil in Southeastern Asia including Malaysia and

90 Indonesia [6]. It is unsuitable for agricultural purposes because of its weak structure,

91 deficient of nutrients, low capacity of water retention, high soil temperature, and

92 ultimately inadequate supports of plants to grow [7-9]. During monsoon seasons, the

93 steep cliffs layers erosion and deposition of residues and sand from the sea is

94 developed by moving sea water and create BRIS soil containing coarse sand

95 components [10]. In Malaysia, BRIS soil is widely distributed in Terengganu, the east

96 coast of Peninsular in Kelantan, Pahang and the west coast of Johor. This soil is 
97 categorized into seven soil series based on drainage, depth and soil profile, including

98 Rhu Tapai, Rusila, Rudua, Rompin, Merchang, Jambu and Baging [11].

99 Although, BRIS soil is known as a problematic soil for agriculture, it is assumed that

100 fertilizer application helps to improve it. During this study, to develop specific soil

101 quality remediation and having soil with a great preference, which will be important

102 requisites in the development of agricultural product, PG organic has been applied to

103 improve BRIS soil.

104 One of the main sources of heavy metals in water (surface and ground water), soil and 105 plants is leachate migration [10-12]. Heavy metals can be transferred to plants

106 through polluted soil and contaminated waste water, and ultimately to the human's

107 foods by vegetables or animal's meat consumption [13-17]. The most challenging 108 heavy metals include chromium $(\mathrm{Cr})$, lead $(\mathrm{Pb})$, zinc $(\mathrm{Zn})$, cadmium $(\mathrm{Cd})$, copper $109(\mathrm{Cu})$ and nickel $(\mathrm{Ni})$ [17-19] contaminate natural environment. However, the toxic 110 effects of both individual and combined heavy metals on humans and other living 111 organisms are mediated by leached dosages, exposure duration and genetic factors $112[20]$.

113 Technogenic and natural environmental radioactivity are the other problem in human

114 environment. Some of environmental radioactivity, like radioisotopes, including 115 strontium-90 $\left({ }^{90} \mathrm{Sr}\right)$ and technetium-99 $\left({ }^{99} \mathrm{Tc}\right)$ are results of human activity and only 116 found on Earth, some other, such as potassium-40 $\left({ }^{40} \mathrm{~K}\right)$ are produced owing to the 117 natural processes and several isotopes like tritium $\left({ }^{3} \mathrm{H}\right)$ are the consequences of both 118 human activities and natural processes [21]. Studies of concentration of 119 environmental radioactive and their activities in various environmental systems are 
120 essential to expect their radiological impacts on Earth. This study was conducted to

121 investigate the accumulated levels of heavy metals (HMs) (e.g., As, Cd, Ce, La, Se,

$122 \mathrm{Sr}$, Th, $\mathrm{Ra}, \mathrm{Zn}, \mathrm{B}, \mathrm{Mn}, \mathrm{Pb}, \mathrm{Cr}, \mathrm{Ag}, \mathrm{Ba}, \mathrm{Al}$, and $\mathrm{Hg}$ ) in water, soil and plants between

123 BRIS soil under PG organic treatment and normal BRIS soil. Furthermore, natural

124 radioactivity concentrations e.g., ${ }^{226} \mathrm{Ra},{ }^{228} \mathrm{Ra},{ }^{238} \mathrm{U}$ and ${ }^{232} \mathrm{Th}$ in the collected samples

125 were measured.

126 Materials and methods

127 Experimental Site

128 The field trial was conducted on 1.62 ha at Kampung Darat Sungai Ular, Pahang 129 (GPS 350'51"N, 103²1'46"E) as shown in Fig. 1.

131 Fig. 1 The location of the experimental site and the Lynas Advance Material Plant 132 (LAMP).

134 The implication of PG organic application to the environment was monitored for two

135 planting seasons beginning in 2015 with 4-month cycles for each season. The residual

136 effect of the PG organic conditioner was measured for three test crops, including corn

137 (Zea mays L.), kenaf (Hibiscus cannabinus L.) and guinea grass (Panicum maximum).

138 Characterization of PG organic using Powder-X ray Diffraction

139 Powder X-ray diffraction (XRD) was performed on a Siemens D500 diffractometer, 140 using the $\mathrm{Cu} \mathrm{K} \alpha$ radiation $(1.5418 \AA$ ). The data collection was carried out from $2 \theta=$ $14110^{\circ}-80^{\circ}$ with a step of $0.02^{\circ}$ and an acquisition time of $10 \mathrm{~s}$. Diffraction data were 
142 analyzed by the Rietveld method, using the fully automated code RIETQUAN [22],

143 which is particularly useful for a quantitative evaluation of phases and reliable

144 structural and microstructural information, such as unit cell, average crystallite size

145 and lattice strain.

\section{Plot Design and Treatment}

147 The randomized complete block design (RCBD) was applied on the experimental site 148 with three replications for two seasons. There are seven treatments applied as shown 149 in Fig. 2.

151 Fig. 2 The sub-plots receiving the PG organic conditioner treatment for 3 cropping seasons for kenaf, maize, and guinea grass. Blue represents the sub-plot receiving the soil conditioner for each cropping season, and yellow represents the sub-plot receiving residual treatment.

156 The PG organic conditioner is a mixture of WLP: NUF: Composted oil palm empty

157 fruit bunch as filler in a ratio 1:2:7, which transferred to the site for immediate use.

158 The PG organic was applied at the top of soil surface and mixed thoroughly in the top

$15915 \mathrm{~cm}$ soil depth using a rotovator machine. There was allowed to equilibrate for 7

160 days before cropping of plants. Fertilizer treatments based on crop recommended rate

161 and frequencies of application were added to top of the soil under the plant canopy,

162 when permissible based on soil and foliar analyses. A drip irrigation water system was

163 applied to each plot using black plastic tape tubing. The water was supplied when

164 necessary to achieve the target moisture content of soil field capacity (FC). All soil,

165 plants and water characteristics were compared between control plots (without PG 
166 organic and fertilizer) and those plots received maximum amount of PG organic as 167 conditioner (T6).

\section{Sampling of Soils, Water and Plants}

169 Soils were sampled on three occasions: before the PG organic application (base line), 170 after the PG organic application (one month after application) and at harvest. Topsoil $171(0-30 \mathrm{~cm})$ samples were taken randomly in a composite manner from the designated 172 plot to determine their physicochemical properties, the nutrient, heavy metal and

173 natural radionuclides contents. Approximately $2 \mathrm{~kg}$ of composite topsoil $(0-30 \mathrm{~cm})$ 174 samples was collected and kept in a plastic bag. Meanwhile, water was sampled from 175 boreholes within or near the plots, and surface water was sampled in the nearby 176 Sungai Ular. In situ water parameters, such as $\mathrm{pH}$, salinity, dissolved oxygen, 177 electrical conductivity, temperature and total dissolved solids were examined in the 178 field using an YSI 556 MPS handheld multi-parameter water quality meter. All water 179 samples collected for laboratory analysis were kept in an ice box with a temperature 180 below $4{ }^{\circ} \mathrm{C}$ and contained the addition of several drops of $\mathrm{HNO}_{3}$ acid to control the $\mathrm{pH}$ 181 below 2. The aboveground mass of plants was cut and sampled for their stems, leaves 182 and grain for corn. The summarized of detailed information regarding the samples is 183 shown in Table 1. 
184 Table 1 Locations of soil, plant and water sampling at UPM plots in Sungai 185 Ular.

\begin{tabular}{|c|c|c|c|}
\hline Season & $\begin{array}{l}\text { Sample } \\
\text { type }\end{array}$ & Sample ID & Note \\
\hline \multirow{14}{*}{$2^{\text {nd }}$ Season } & \multirow{3}{*}{ Soil } & $\begin{array}{l}\text { Kenaf-Soil-Control } \\
\text { Kenaf-Soil-Control }\end{array}$ & Control sample without PG organic \\
\hline & & Kenaf-Soil-PG organic & \multirow[b]{2}{*}{ Soil treated with PG organic } \\
\hline & & $\begin{array}{c}\text { Guinea grass--Soil-PG } \\
\text { organic }\end{array}$ & \\
\hline & \multirow{7}{*}{ Water } & BH-1 & \multirow{5}{*}{ Underground water } \\
\hline & & BH-2 & \\
\hline & & BH-3 & \\
\hline & & BH-4 & \\
\hline & & $\mathrm{BH}-5$ & \\
\hline & & SW-1 & \multirow{2}{*}{ Surface water (river) } \\
\hline & & SW-2 & \\
\hline & \multirow{4}{*}{ Plant } & Kenaf-stem-Control & \multirow[b]{2}{*}{ Plant growing without PG organic } \\
\hline & & $\begin{array}{c}\text { Guinea grass-leaf- } \\
\text { Control }\end{array}$ & \\
\hline & & Kenaf-stem-PG organic & \multirow[b]{2}{*}{ Plant Growing with PG organic } \\
\hline & & $\begin{array}{c}\text { Guinea grass-leaf-PG } \\
\text { organic }\end{array}$ & \\
\hline
\end{tabular}


196 Continued Table 1: Locations of soil, plant and water sampling at UPM plots in 197 Sungai Ular.

\begin{tabular}{|c|c|c|c|}
\hline Season & $\begin{array}{l}\text { Sample } \\
\text { type }\end{array}$ & Sample ID & Note \\
\hline \multirow{15}{*}{$3^{\text {nd }}$ Season } & \multirow{4}{*}{ Soil } & Kenaf-Soil-Control & \multirow{2}{*}{ Control sample without PG organic } \\
\hline & & Kenaf-Soil-Control & \\
\hline & & Kenaf-Soil-PG organic & \multirow[b]{2}{*}{ Soil treated with PG organic } \\
\hline & & $\begin{array}{c}\text { Guinea grass--Soil-PG } \\
\text { organic }\end{array}$ & \\
\hline & \multirow{7}{*}{ Water } & BH-1 & \multirow{5}{*}{ Underground water } \\
\hline & & BH-2 & \\
\hline & & BH-3 & \\
\hline & & BH-4 & \\
\hline & & BH-5 & \\
\hline & & SW-1 & \multirow[b]{2}{*}{ Surface water (river) } \\
\hline & & SW-2 & \\
\hline & \multirow{4}{*}{ Plant } & Kenaf-stem-Control & \multirow[b]{2}{*}{ Plant growing without PG organic } \\
\hline & & $\begin{array}{l}\text { Guinea grass-leaf- } \\
\text { Control }\end{array}$ & \\
\hline & & Kenaf-stem-PG organic & \multirow[b]{2}{*}{ Plant Growing with PG organic } \\
\hline & & $\begin{array}{c}\text { Guinea grass-leaf-PG } \\
\text { organic }\end{array}$ & \\
\hline
\end{tabular}

198 Characterization of Soil Physico-chemical Properties

199 Soils were tested for their particle size distribution and organic matter content. The

200 particle size distribution was determined using the pipette method together with dry

201 sieving [23], whereas organic matter was determined by the loss on ignition method

202 [23]. Soil chemical tests involved the $\mathrm{pH}\left(\mathrm{H}_{2} \mathrm{O}\right)$, nutrient contents $(\mathrm{Ca}, \mathrm{Mg}, \mathrm{K}$, and $\mathrm{P})$,

203 organic carbon content, electrical conductivity and heavy metals. The soil $\mathrm{pH}$ in water

204 was determined at soil: solution ratio (1/2.5) and measured using a pH meter. Organic

205 carbon was measured with the Walkley and Black [24] method. Electrical 
206 conductivity was measured in saturated gypsum extracts [25]. The total C, N, and S

207 were measured using a CHNS analyzer (Model: LECO CHNS-932).

\section{Analysis of Heavy Metal}

209 Soils

210 Soil samples were dried at room temperature, ground and sieved to pass through a 2-

$211 \mathrm{~mm}$ sieve. For the determination of heavy metal contents, the soil was pulverized to

212 pass through 63-micron sieves. Plant samples were cleaned in running water and

213 rinsed with deionized water at least three times before being cut into small pieces,

214 dried and ground using a micro-hammer mill. The total heavy metal contents in the

215 soil was extracted with nitric acid and perchloric acid in a 3:1 ratio [26]. Heavy metal

216 contents (As, Cd, Ce, La, Se, Sr, Th, Zn, B, Mn, Pb, Cr, Ag, Ba, Al, and Hg) were

217 extracted by the wet digestion method. Heavy metals in solution were determined

218 using the ICP-MS (Model: Perkin Elmers Elan 9000).

\section{Water}

220 The water analysis followed the standard methods proposed by American Public

221 Health Association, APHA [27]. Heavy metal contents in water (e.g., As, Cd, Ce, La,

$222 \mathrm{Se}, \mathrm{Sr}, \mathrm{Th}, \mathrm{Ra}, \mathrm{Zn}, \mathrm{B}, \mathrm{Mn}, \mathrm{Pb}, \mathrm{Cr}, \mathrm{Ag}, \mathrm{Ba}, \mathrm{Al}$, and $\mathrm{Hg}$ ) were measured using ICP-MS.

\section{Plants}

224 The plant parts were separated into roots, stems, leaves and grain and analyzed for 225 heavy metals and nutrient. The total heavy metal contents of the plants were extracted 226 with nitric acid and hydrogen peroxide in a 3:1 ratio [28]. The heavy metal contents 227 determined included As, Cd, Ce, La, Se, Sr, Th, Zn, B, Mn, Pb, Cr, Ag, Ba, Al, and 228 Hg. Heavy metals in solution extracts were determined using ICP-MS. 


\section{Sample preparation}

231 Each sample was prepared accordance to the International Atomic Energy Agency 232 (IAEA) guidelines [29]. The soil and plant samples were cleaned and dried in the 233 oven at $105^{\circ} \mathrm{C}$ for 72 hours, until a constant weight was achieved. Soil and plant

234 samples were then left to cool at room temperature, ground using a grinder and sieved 235 with a $500 \mu \mathrm{m}$ sieve size to ensure the homogeneity of the samples. Meanwhile, water 236 samples were filtered out from impurities using a clean dried sieve cloth. The samples 237 were then packed into Marinelli counting beaker, sealed and for 30 days to attain 238 secular equilibrium between the parents' radionuclides $\left({ }^{238} \mathrm{U}\right.$ and $\left.{ }^{232} \mathrm{Th}\right)$ and their 239 respective progenies.

\section{Gamma spectrometry analysis}

241 Natural radioactivity in samples was determined after 12 hours of counting using a 242 gamma spectrometry system with a Canberra High-purity Germanium Detector 243 (HPGe) coupled to a multichannel analyzer. The HPGe detector was shielded inside 244 CANBERRA model-747 lead shielding coated with tin and copper to provide a low 245 background environment. The radioactivity concentrations of ${ }^{226} \mathrm{Ra},{ }^{232} \mathrm{Th}$ and ${ }^{40} \mathrm{~K}$ 246 were determined through gamma-ray photo peaks of $1764 \mathrm{keV}\left({ }^{214} \mathrm{Bi}\right), 2614 \mathrm{keV}$ $247\left({ }^{208} \mathrm{Tl}\right)$ and $1460 \mathrm{keV}\left({ }^{40} \mathrm{~K}\right)$ with the corresponding emission probability of $15.2,99.8$ 248 and $10.7 \%$, respectively. The gamma spectrometry system was calibrated using a 249 standard source with a mixture of ${ }^{22} \mathrm{Na},{ }^{51} \mathrm{Cr},{ }^{57} \mathrm{Co},{ }^{60} \mathrm{Co},{ }^{85} \mathrm{Sr},{ }^{88} \mathrm{Y},{ }^{109} \mathrm{Cd},{ }^{113} \mathrm{Sn},{ }^{137} \mathrm{Cs}$,

$250{ }^{123} \mathrm{Te}$ and ${ }^{241} \mathrm{Am}$ radionuclides. The analysis of gamma spectra was performed using 251 Genie-2000 software supplied by CANBERRA. The IAEA Soil-375 (certified 
252 reference material), IARMA-004 (certified reference material) and 0802 Silica

253 Standard (Multinuclide Standard Mixed with Silica) were used as reference in this

254 research. The counting errors were quoted at 1-sigma absolute. Natural radionuclide

255 concentrations in soil and plant samples were determined using Equation 1 and

256 Equation 2, respectively, as follows [30-31].

$257 \quad \mathrm{~W}_{\mathrm{s}}=\frac{M r m \times A s}{M s \times A r m} \times \mathrm{W}_{\mathrm{r} \mathrm{m}}$

$258 \quad \mathrm{~W}_{\mathrm{s}}=\frac{A s}{\epsilon \theta M S}$

259 The $\mathrm{W}_{\mathrm{s}}$ and $\mathrm{W}_{\mathrm{rm}}$ are radionuclide concentrations for sample and reference materials in

$260 \mathrm{~Bq} \mathrm{~kg}^{-1}, \mathrm{M}_{\mathrm{s}}$ and $\mathrm{M}_{\mathrm{rm}}$ are sample and reference material masses (g), while, As and Arm

261 are the activities (net count per second, cps) for sample and reference materials,

262 respectively. The $\epsilon$ and $\theta$ are the energy efficiency and abundance of the interest

263 gamma energy peak, respectively. The accuracy of the procedure was checked by

264 measuring the IAEA Soil-375 under the same condition and samples. The lower limit

265 detection (LLD) and the measured activity of ${ }^{226} \mathrm{Ra},{ }^{232} \mathrm{Th}$ and ${ }^{40} \mathrm{~K}$ are summarized in

266 Table 2.

Table 2 Comparison between the measured radioactivity concentrations and the recommended values by IAEA.

\begin{tabular}{|c|c|c|c|}
\hline \multirow[b]{2}{*}{ Radionuclides } & \multicolumn{3}{|c|}{ IAEA CRM-375 } \\
\hline & $\begin{array}{l}\text { Recommended value } \\
\left(\mathrm{Bq} \mathrm{kg}^{-1}\right)\end{array}$ & $\begin{array}{l}\text { Measured value } \\
\left(\mathrm{Bq} \mathrm{kg}^{-1}\right)\end{array}$ & $\begin{array}{l}\operatorname{LLD}(\mathrm{Bq} \\
\left.\mathrm{kg}^{-1}\right)\end{array}$ \\
\hline${ }^{226} \mathrm{Ra}\left({ }^{238} \mathrm{U}\right.$ series $)$ & $24.4 *(19-29.8)^{* *}$ & 20.5 & 0.3 \\
\hline${ }^{228} \mathrm{Ra}\left({ }^{232} \mathrm{Th}\right.$ series $)$ & $20.5(19.2-21.9)$ & 21.7 & 0.2 \\
\hline${ }^{40} \mathrm{~K}$ & $424(417-432)$ & 430.6 & 1.2 \\
\hline
\end{tabular}

270 Note: * Certified value; $* *$ Certified value within $95 \%$ confidence level. 


\section{Determination of Pollution Indices}

273 The guidelines used as a comparison to the heavy metal contents in water were the

274 available standard, such as the new Dutch List [32], Malaysian Guidelines for Raw

275 Water Quality Criteria [33] and the National Water Quality Standard (NWQS). The

276 metal contents in soil were compared with the new Dutch List [32], and the metal

277 contents in the grain were compared with values from the Malaysian Food Act [34]

278 and Food Regulation [35] standard.

\section{$279 \quad$ 2.8.1 Biological accumulation coefficient}

280 The biological accumulation coefficient (BAC), which is an indicator of the ability of

281 a plant to accumulate a specific metal in contrast to the concentration of the metal in

282 the soil substrate [36], was calculated as follows:

$$
\mathrm{BAC}=\frac{\text { Metal concentration in plant }}{\text { Metal concentration in soil }}
$$

284 Where, the heavy metal concentrations in the edible parts of the plant and the soil are

285 represented by metal concentration in the plant and metal concentration in the soil, 286 respectively.

\section{$287 \quad 2.8 .2 \quad$ Geo-accumulation index}

288 Established by Muller [37], the geo-accumulation Index (I-geo) was used to discover

289 how much metal has built up in sediments and has been employed in a number of 290 applications and for a number of research purposes. The I-geo is mathematically 291 expressed as:

292 I-geo $=\log _{2}\left(\mathrm{Cn} / 1.5 \mathrm{~B}_{\mathrm{n}}\right)$, where $\mathrm{C}_{\mathrm{n}}=$ Concentration of element in the soil sample, and $293 \quad B_{n}=$ the geochemical background value. 
294 Factor 1.5 is used in the equation to take into consideration the chance of disparities in 295 background data because of lithogenic factors. The I-geo scale is made up of seven 296 levels $(0-6)$, from no contamination to heavy pollution.

\section{$297 \quad 2.8 .3 \quad$ Pollution load index}

298 The pollution index (PLI) is composed of contamination factors (CF), which are the 299 quotients given by the division of the concentration of each metal. The CF is made of 300 four levels $(0-3$, low CF to high CF) [38]. The PLI of the site is estimated by

301 gathering the n-root from the CFs, which were found from the metals the PLI 302 gathered from each location [39]. The PLI was created by Tomlinson et al. [40] using 303 the formula below:

$$
\mathrm{PLI}=\sqrt[\mathrm{n}]{(\mathrm{CFI} \times \mathrm{CF} 2 \times \mathrm{CF} 3 \ldots \times \mathrm{CFn}}
$$

306 Where, $\mathrm{CF}=$ contamination factor, $\mathrm{n}=$ number of metals, $\mathrm{C}$ metal $=$ the metal

307 concentration in soil samples and $\mathrm{C}$ Background value $=$ the background value of that 308 metal.

\section{Determination of radiological hazard Index}

310 A radium equivalent $\left(\mathrm{Ra}_{\mathrm{eq}}\right)$ was used to estimate radiological hazard index (RHI). The

311 significance of ${ }^{226} \mathrm{Ra}{ }^{232} \mathrm{Th}$, and ${ }^{40} \mathrm{~K}$ concentrations, with respect to radiation exposure, 312 was defined in terms of Raeq activity in $\mathrm{Bq} \mathrm{kg}^{-1}$. The $\mathrm{Ra}_{\mathrm{eq}}$ was calculated using the 313 following equation [41]:

$314 \quad \mathrm{Ra}_{\mathrm{eq}}=\mathrm{C}_{\mathrm{Ra}}+1.47 \mathrm{C}_{\mathrm{Th}}+0.077 \mathrm{C}_{\mathrm{K}}$ 
315 Where, $\mathrm{C}_{\mathrm{Ra}}, \mathrm{C}_{\mathrm{Th}}$, and $\mathrm{C}_{\mathrm{K}}$ are the activity concentrations of ${ }^{226} \mathrm{Ra},{ }^{228} \mathrm{Ra}$, and ${ }^{40} \mathrm{~K}$ in $\mathrm{Bq}$

$316 \mathrm{~kg}^{-1}$, respectively. This equation is based on the estimation that $10 \mathrm{pCi}$ g- 1 of ${ }^{226} \mathrm{Ra}, 7$

$317 \mathrm{pCi} \mathrm{g}^{-1}$ of ${ }^{232} \mathrm{Th}$ and $130 \mathrm{pCi} \mathrm{g}^{-140} \mathrm{~K}$ will produce the same gamma dose rates [41-42].

318 The value of $\mathrm{Ra}_{\mathrm{eq}}$ should be less than $370 \mathrm{~Bq} \mathrm{~kg}^{-1}$ to be safe for agricultural

319 applications or building materials, as recommended by Nuclear Energy Agency

320 (NEA) and Organization for Economic Co-operation and Development (OECD) [43].

\section{Determination of radionuclide uptakes by plant}

322 The uptake of ${ }^{226} \mathrm{Ra},{ }^{228} \mathrm{Ra},{ }^{238} \mathrm{U},{ }^{232} \mathrm{Th}$ and ${ }^{40} \mathrm{~K}$ from soil to plants was determined

323 using a parameter known as the transfer factor (TF), as follows [44]:

$324 \mathrm{TF}=\frac{\mathrm{Cp}}{\mathrm{Cs}}(5)$

325 Where, $\mathrm{Cp}$ and $\mathrm{Cs}$ are the concentrations of radionuclides of interest in plants and soil

$326\left(\mathrm{~Bq} \mathrm{~kg}^{-1}\right)$, respectively. The transfer factor is used to describe the soil-to-plant transfer

327 of radionuclides through the plant roots.

\section{Quality assurance of heavy metal analysis}

329 Quality assurance/quality control (QA/QC) was addressed by including blanks and

330 replicates for the water, soil, and plant tissue samples. Standard reference materials

331 (SRM) of the National Institute and Technology (NIST, 1640a for water, SRM-2711a

332 Montana II soil, SRM 1568b rice flour and CRM-LGC7162 strawberry leaf) and 333 internal reference materials were used for precision, quality assurance and control

334 (QA/QC) for selected metal measurements. The average values of three replicates

335 were taken for each determination. The precision of analytical procedures was 336 expressed as the relative standard deviation (RSD), which ranged from $5-15 \%$ and 
337 was calculated from the standard deviation divided by the mean. The recovery rates of

338 the studied metals were within $85 \pm 15 \%$. Chemicals, stock solutions, and reagents

339 were obtained from Sigma/Fluka/Merck and were of analytical grade. All glassware

340 was washed with distilled water, soaked in nitric acid (30\%) overnight, rinsed in

341 deionized water and air dried before use.

\section{Statistical Analysis}

343 All the data were analyzed using the Statistical Analysis System (SAS) version 9.4

344 software. All data were subjected to an analysis of variance (ANOVA) statistical

345 analysis to detect the variation of metal contents at different sampling times, which

346 coincided with the PG organic application. A comparison of means was performed

347 using the least significant difference (LSD) test for other crops and Student Newman

348 Keuls test for teak trees. The seedling growth model using linear regression was tested

349 for significance in the software.

\section{$350 \quad$ Results and discussion}

\section{Characterization of PG organic}

352 The XRD pattern (Fig. 3) matches well with the reported pattern for the gypsum

353 (Calcium sulfate hydrate) (PDF 00-033-0311) and deploy the monoclinic geometry 354 (SG: $C 2 / C(15)$.

355 Fig. 3 The XRD diffractogram of PG organic conditioner using PXRD method.

357 The pattern indicates that the sample is crystallized, and the lattice parameter was 358 calculated to be, $a=6.284, b=15.20, c=5.677$. However, there are other heavy metals 
359 existing on a sample, including thorium, magnesium, and carbon. The XRD peaks of

$360 \mathrm{ThO}_{2}$ are in good agreement with the cubic geometry (SG: $F m 3 m$ ) with the lattice

361 constants $a=5.597 \AA$, which is a good agreement with reported in the literature for

362 bulk $\mathrm{ThO}_{2}(\mathrm{PDF} 00-042-1462)$.

\section{Physico-chemical Properties of Soil}

364 Physico-chemical properties of baseline soil before and after PG organic

365 application

366 The soil is a sandy type, with particles dominated by more than $80 \%$ sand (Table 3 ).

367

368 Table 3 Soil properties before and after PG organic application at Sungai Ular 369 research plots.

370

\begin{tabular}{|c|c|c|c|c|c|c|c|c|}
\hline \multirow[t]{3}{*}{ Parameter } & \multicolumn{8}{|c|}{ Sampling frequency } \\
\hline & \multirow{2}{*}{$\begin{array}{c}\text { 22-05-2015 } \\
\text { before } \\
\text { (baseline) }\end{array}$} & \multirow{2}{*}{$\begin{array}{c}\text { 22-01-2016 } \\
\text { after } \\
\text { PG organic } \\
\text { application }\end{array}$} & \multicolumn{2}{|c|}{$\begin{array}{c}27-09-2016 \\
\text { Harvest } 1\end{array}$} & \multicolumn{2}{|c|}{$\begin{array}{c}08-12-2016 \\
\text { Harvest } 2\end{array}$} & \multicolumn{2}{|c|}{$\begin{array}{c}24-04-2017 \\
\text { Harvest } 3\end{array}$} \\
\hline & & & Control & Max & Control & Max & Control & Max \\
\hline Sand $(\%)$ & 87 & 90 & ND & ND & 90 & 91 & 84 & 85 \\
\hline Silt (\%) & 8 & 4 & ND & ND & 7 & 5 & 9 & 8 \\
\hline Clay (\%) & 5 & 6 & ND & ND & 3 & 4 & 7 & 7 \\
\hline Texture & Sand & Sand & ND & ND & Sand & Sand & Sand & Sand \\
\hline Organic matter (\%) & 6.14 & 5.45 & 5.02 & 5.25 & 6.10 & 5.78 & 5.60 & 5.64 \\
\hline $\mathrm{pH}$ water & 4.11 & 4.63 & 5.13 & 5.34 & 4.15 & 4.25 & 5.79 & 6.08 \\
\hline $\mathrm{EC}(\mathrm{mS} / \mathrm{cm})$ & 2.04 & 2.05 & 1.87 & 1.96 & 1.94 & 1.94 & 1.99 & 2.10 \\
\hline $\operatorname{Exch~Al~}\left(\mathrm{cmol}^{+} / \mathrm{kg}\right)$ & 0.47 & 0.04 & ND & ND & 0.01 & 0.01 & 0.05 & 0.04 \\
\hline Exch $\mathrm{H}\left(\mathrm{cmol}^{+} / \mathrm{kg}\right)$ & 0.33 & 0.01 & ND & ND & 0.02 & 0.01 & 0.04 & 0.03 \\
\hline $\operatorname{ExchCa}\left(\mathrm{cmol}^{+} / \mathrm{kg}\right)$ & 0.34 & 0.59 & ND & ND & 1.53 & 1.70 & 0.16 & 0.22 \\
\hline Exch $\mathrm{Mg}\left(\mathrm{cmol}^{+} / \mathrm{kg}\right)$ & 0.34 & 0.37 & ND & ND & 0.86 & 1.01 & 0.71 & 0.69 \\
\hline Exch $\mathrm{Na}\left(\mathrm{cmol}^{+} / \mathrm{kg}\right)$ & 0.19 & 0.11 & ND & ND & 1.52 & 1.18 & 0.22 & 0.36 \\
\hline Exch K $\left(\mathrm{cmol}^{+} / \mathrm{kg}\right)$ & 0.09 & 0.30 & ND & ND & 0.45 & 0.46 & 0.09 & 0.09 \\
\hline $\mathrm{CEC}\left(\mathrm{cmol}^{+} / \mathrm{kg}\right)$ & 1.75 & 1.41 & ND & ND & 4.38 & 4.36 & 1.20 & 1.42 \\
\hline Available P (mg/kg) & 2.44 & 5.35 & ND & ND & 1.60 & 1.39 & 1.90 & 2.04 \\
\hline Total C (\%) & 1.70 & 3.17 & 2.92 & 3.05 & 16.80 & 15.17 & 2.30 & 2.48 \\
\hline Total N (\%) & 1.16 & 1.05 & 0.16 & 0.02 & 0.28 & 0.28 & 0.10 & 0.22 \\
\hline Total S (\%) & 0.13 & 0.13 & 0.01 & 0.02 & 0.12 & 0.09 & 0.02 & 0.02 \\
\hline $\mathrm{C} / \mathrm{N}$ ratio & 1.47 & 3.02 & 18.25 & 152.50 & 59.36 & 54.40 & 22.35 & 13.02 \\
\hline
\end{tabular}

Note: ND:Inot detected; Max: maximum treatment. 
372 The organic matter content remained unchanged throughout the study period. Soil $\mathrm{pH}$

373 was strongly acidic but improved significantly at the last harvest from 4.11 to 5.64.

374 The electrical conductivity (EC) and cation exchange capacity (CEC) remain

375 unchanged throughout the study period, with value of $\square 2.0 \mathrm{mS} / \mathrm{cm}$ and $<2.0 \mathrm{cmol}^{+} / \mathrm{kg}$

376 soil, respectively. The CEC value was extremely low, which is typical for BRIS soil.

377 The available $\mathrm{P}$ showed no significant difference before and after the PG organic

378 treatment. Total C significantly increased from 1.7 to $3.47 \%$ after PG organic

379 application; however, total $\mathrm{N}$ and $\mathrm{S}$ showed the opposite trend.

\section{Effects of PG organic application on water surface and boreholes in the study area}

381 The $\mathrm{pH}$ values of surface water and water in the boreholes were acidic (Table 4). The

$382 \mathrm{pH}$ of water in the borehole was within Class IV of the National Water Quality

383 Standard (Environmental Quality Report, 2013). The pH of surface water was below

384 the Class IV range in the NWQS standard. Other in situ parameters fluctuated during

385 different sampling times. This in situ parameter could be influenced by the amount of

386 water in the borehole and stream due to changing seasons and the rising and falling of

387 the tide. 
Table 4 Physico-chemical properties and macronutrients contents in boreholes and surface water before and after PG organic application.

\begin{tabular}{|c|c|c|c|c|c|c|c|c|c|c|c|}
\hline \multirow[t]{2}{*}{ Paramete } & & \multirow{2}{*}{$\begin{array}{c}\text { Baseline } \\
(22-05-2015) \\
\\
\text { Surface } \\
\text { Water }\end{array}$} & \multicolumn{2}{|c|}{$\begin{array}{l}\text { After PG organic } \\
\text { application } \\
(22-01-2016)\end{array}$} & \multicolumn{2}{|c|}{$\begin{array}{c}\text { After PG organic } \\
\text { application Harvest } 1 \\
(17-09-2016)\end{array}$} & \multicolumn{2}{|c|}{$\begin{array}{c}\text { After PG organic } \\
\text { application } \\
\text { Harvest } 2 \\
(08-12-2016)\end{array}$} & \multicolumn{2}{|c|}{$\begin{array}{c}\text { After PG organic } \\
\text { application } \\
\text { Harvest } 3 \\
(10-05-2017)\end{array}$} & \multirow[t]{2}{*}{$\begin{array}{c}\text { Class IV } \\
\text { NWQS }\end{array}$} \\
\hline & Borehole & & Borehole & $\begin{array}{l}\text { Surface } \\
\text { Water }\end{array}$ & Borehole & $\begin{array}{c}\text { Surface } \\
\text { Water }\end{array}$ & Borehole & $\begin{array}{l}\text { Surface } \\
\text { Water }\end{array}$ & Borehole & $\begin{array}{l}\text { Surface } \\
\text { Water }\end{array}$ & \\
\hline $\mathrm{pH}$ & 4.70 & 5.08 & 6.10 & 4.44 & 5.89 & 4.29 & 5.69 & 3.96 & 4.93 & 5.04 & $5-9$ \\
\hline Temp $\left({ }^{\circ} \mathrm{C}\right)$ & - & - & 24.96 & 24.35 & 25.70 & 25.23 & 25.23 & 24.58 & 29.47 & 30.12 & - \\
\hline $\mathrm{EC} \mathrm{mS/cm)}$ & 0.06 & 6.52 & 0.04 & 0.08 & 0.05 & 82.00 & 0.07 & 0.40 & 0.11 & 0.30 & 6 \\
\hline TDS (g/L) & - & - & 26.00 & 51.50 & 84.40 & 237.50 & 0.05 & 0.26 & 65.60 & 176.50 & 4000 \\
\hline Salinity (\%) & - & - & 0.02 & 0.04 & 0.06 & 0.20 & 0.03 & 0.20 & 0.05 & 0.13 & 2 \\
\hline DO (mg/L) & - & - & 2.98 & 4.53 & 4.52 & 5.45 & 5.37 & 2.93 & 5.61 & 7.58 & $<3$ \\
\hline $\mathrm{Al}(\mu \mathrm{g} / \mathrm{L})$ & 37.43 & 804.64 & 12.42 & 631.10 & 97.93 & 420.54 & 48.35 & 554.07 & 261.59 & 607.21 & NL \\
\hline $\mathrm{Ca}(\mu \mathrm{g} / \mathrm{L})$ & 2681.89 & 33978.22 & 2229.5 & 1827.4 & 1149.86 & 2626.9 & 1074.8 & 707.21 & 1285.22 & 781.52 & NL \\
\hline $\operatorname{Mg}(\mu \mathrm{g} / \mathrm{L})$ & 667.20 & 193666.9 & 684.64 & 1151.9 & 1904.50 & 3679.5 & 766.83 & 537.17 & 10595.62 & 6958.86 & $\mathrm{NL}$ \\
\hline $\mathrm{K}(\mu \mathrm{g} / \mathrm{L})$ & 1543.86 & 42289.70 & 1736.7 & 1656.0 & 2614.78 & 5648.2 & 1289.2 & 828.94 & 5989.34 & 3481.78 & $\mathrm{NL}$ \\
\hline $\mathrm{Na}(\mu \mathrm{g} / \mathrm{L})$ & & & & & 4041.91 & 6010.9 & 1335.1 & 2012.1 & 2700.6 & 94031.1 & $\mathrm{NL}$ \\
\hline
\end{tabular}

390Note: ND: not detected; Source of standard: *Malaysian Standard for Raw Drinking Water Quality [33]; the new Dutch list [32]; within rows,

39 means followed by a common letter are not significantly different using LSD test at the 5\% level of significance. 
392 The salinity and EC readings in the boreholes were lower than the limit in the Class

393 IV standard. Surface water recorded a high EC reading at the baseline compared to

394 the Class IV standard. A high DO reading of more than $3 \mathrm{mg} / \mathrm{L}$ indicated that both

395 boreholes and surface water were much better than Class IV in the NWQS standard.

396 The cation contents ( $\mathrm{Al}, \mathrm{Ca}, \mathrm{Mg}$ and $\mathrm{K}$ ) in the surface water and in the boreholes

397 varied significantly with time of sampling.

398 Effects of PG organic conditioner on nutritional values of plants

399 Nutrient contents in plants and corn grain in three harvests are presented in Table 5.

400 Nutrient contents in the plants of the plot treated with PG organic were compared with

401 the control plot.

402 Macronutrients in control plants (Table 5) showed a significantly higher content

$403(\mathrm{p}<0.05)$ or were not significantly different $(\mathrm{p}>0.05)$ from the PG organic treated

404 plant. Total N, C, and S contents also showed a similar level in treated and control

405 plants. The macronutrient contents in corn grains treated with PG organic were not

406 significantly different $(p>0.05)$ or significantly lower than $(p<0.05)$ the control (Table $4075)$.

408 Carbon, $\mathrm{N}$ and $\mathrm{S}$ follow a similar pattern. There were significant increases in $\mathrm{K}$ and $\mathrm{P}$

409 in the third harvest season compared to the second harvest season. An increase in

410 macronutrients is considered normal since they are extensively used as conventional

411 fertilizer in agriculture. 
Table 5 Nutrient contents of cultivated plants and corn grain in Sungai Ular research plots.

\begin{tabular}{|c|c|c|c|c|c|c|}
\hline \multirow[t]{3}{*}{ Parameter (Plants) } & \multicolumn{6}{|c|}{ Sampling frequency } \\
\hline & \multicolumn{2}{|c|}{$27-09-2016$} & \multicolumn{2}{|c|}{$08-12-2016$} & \multicolumn{2}{|c|}{ 24-04-2017 } \\
\hline & Control & $\operatorname{Max}$ & Control & Max & Control & $\operatorname{Max}$ \\
\hline Total $\mathrm{Ca}(\mathrm{mg} / \mathrm{kg})$ & $1934.67 \mathrm{a}$ & $914.70 \mathrm{~b}$ & $1981.95 \mathrm{a}$ & $1909.94 \mathrm{a}$ & NPG & $1651.62 \mathrm{a}$ \\
\hline Total $\mathrm{Mg}(\mathrm{mg} / \mathrm{kg})$ & $1306.91 \mathrm{c}$ & $1966.74 b$ & $10862.66 \mathrm{a}$ & $9402.54 \mathrm{a}$ & NPG & $1987.68 b$ \\
\hline Total K (mg/kg) & $5164.62 \mathrm{a}$ & $3433.87 \mathrm{~b}$ & $6877.75 \mathrm{a}$ & $2271.21 \mathrm{c}$ & NPG & $1745.17 \mathrm{~d}$ \\
\hline Total Al (mg/kg) & - & - & $92.86 \mathrm{a}$ & $53.00 \mathrm{~b}$ & NPG & $78.06 \mathrm{a}$ \\
\hline Total P (mg/kg) & $945.30 \mathrm{~b}$ & $829.45 b$ & $1968.21 \mathrm{a}$ & $2043.75 \mathrm{a}$ & NPG & $791.64 c$ \\
\hline Total C (\%) & - & - & $40.30 \mathrm{a}$ & $40.23 \mathrm{a}$ & NPG & $39.70 \mathrm{a}$ \\
\hline Total N (\%) & - & - & $1.26 \mathrm{a}$ & $1.28 \mathrm{a}$ & NPG & $1.27 \mathrm{a}$ \\
\hline Total S (\%) & - & - & $0.39 \mathrm{a}$ & $0.39 \mathrm{a}$ & NPG & $0.38 \mathrm{a}$ \\
\hline $\mathrm{C} / \mathrm{N}$ ratio & - & - & $31.89 \mathrm{a}$ & $31.52 \mathrm{a}$ & NPG & $31.26 \mathrm{a}$ \\
\hline \multirow{2}{*}{$\begin{array}{l}\text { Parameter (corn } \\
\text { grain) }\end{array}$} & \multicolumn{2}{|c|}{ 27-09-2016 } & \multicolumn{2}{|c|}{ 08-12-2016 } & \multicolumn{2}{|c|}{ 24-04-2017 } \\
\hline & Control & $\operatorname{Max}$ & Control & Max & Control & Max \\
\hline Total $\mathrm{Ca}(\mathrm{mg} / \mathrm{kg})$ & - & - & $1879.24 \mathrm{a}$ & $1449.51 b$ & $27.50 \mathrm{c}$ & $33.01 \mathrm{c}$ \\
\hline Total Mg (mg/kg) & - & - & $1964.66 a$ & $1954.59 a$ & $735.95 b$ & $820.60 b$ \\
\hline Total K (mg/kg) & - & - & $2333.09 \mathrm{~b}$ & $1658.17 \mathrm{c}$ & $15301.32 \mathrm{a}$ & $16092.46 \mathrm{a}$ \\
\hline Total $\mathrm{Al}(\mathrm{mg} / \mathrm{kg})$ & - & - & $75.67 \mathrm{a}$ & $79.06 \mathrm{a}$ & $28.27 \mathrm{~b}$ & $11.04 \mathrm{c}$ \\
\hline Total P $(\mathrm{mg} / \mathrm{kg})$ & - & - & $1587.28 b$ & $695.60 \mathrm{c}$ & $2759.50 \mathrm{a}$ & $3240.87 \mathrm{a}$ \\
\hline Total C (\%) & - & - & $40.21 \mathrm{a}$ & $39.61 \mathrm{a}$ & $33.25 \mathrm{~b}$ & $34.98 b$ \\
\hline Total N (\%) & - & - & $1.26 \mathrm{a}$ & $1.27 \mathrm{a}$ & $0.75 c$ & $0.93 b$ \\
\hline Total S (\%) & - & - & $0.39 \mathrm{a}$ & $0.39 \mathrm{a}$ & $0.08 \mathrm{c}$ & $0.12 b$ \\
\hline $\mathrm{C} / \mathrm{N}$ ratio & - & - & 31.88 & 31.14 & 44.53 & 37.48 \\
\hline
\end{tabular}

414 Note: ND: not detectable; max: maximum treatment; NPG: no plant growing; within rows, means followed by a common letter are not 415 significantly different using LSD test at the $5 \%$ level of significance. 


\section{Heavy metal measurements}

417 Heavy metals concentrations of baseline soil before and after PG organic 418 application

419 The content of cytotoxic (As, $\mathrm{Cd}, \mathrm{Cr}, \mathrm{Pb}, \mathrm{Hg}$ and $\mathrm{Se}$ ) heavy metals in soil after PG

420 organic application did not show a significant increase from the metal contents before

421 PG organic applications throughout the study period (Table 6). All values were well

422 below the target values stipulated in the New Dutch List [32]. Phytotoxic metals

423 showed a significant $(\mathrm{p}<0.05)$ increase in $\mathrm{Zn}$ and $\mathrm{Mn}$ contents, but not B (Table 6).

424 Zinc and Mn are plant micronutrients normally added to fertilizer as trace elements to

425 improve plant growth and yield. The $\mathrm{Zn}$ content in the soil was lower than the target

426 values provided by the New Dutch List [32].

427 For the content of other metals, $\mathrm{Ce}, \mathrm{Sr}$ and La showed significantly higher contents in

428 the maximum PG organic treatment at the second harvest compared to the baseline 429 data but decreased significantly at the third harvest. 
Table 6 Heavy metals content of soil before and after PG organic application at Sungai Ular research plots.

\begin{tabular}{|c|c|c|c|c|c|c|c|c|c|}
\hline \multirow{3}{*}{$\begin{array}{l}\text { Heavy metals } \\
(\mathrm{mg} / \mathrm{kg})\end{array}$} & \multicolumn{8}{|c|}{ Sampling frequency } & \multirow{3}{*}{$\begin{array}{l}\text { Target value* } \\
(\mathrm{mg} / \mathrm{kg})\end{array}$} \\
\hline & \multirow{2}{*}{$\begin{array}{c}\text { 22-05-2015 } \\
\text { Before } \\
\text { (baseline) }\end{array}$} & \multirow{2}{*}{$\begin{array}{l}\text { 22-01-2016 } \\
\begin{array}{c}\text { After PG organic } \\
\text { application }\end{array}\end{array}$} & \multicolumn{2}{|c|}{$\begin{array}{c}\text { 27-09-2016 } \\
\text { Harvest } 1\end{array}$} & \multicolumn{2}{|c|}{$\begin{array}{c}\text { 08-12-2016 } \\
\text { Harvest } 2\end{array}$} & \multicolumn{2}{|c|}{$\begin{array}{c}\text { 24-04-2017 } \\
\text { Harvest } 3\end{array}$} & \\
\hline & & & Control & Max & Control & $\operatorname{Max}$ & Control & Max & \\
\hline Total As & $4.03 \mathrm{~b}$ & $2.97 \mathrm{bc}$ & $2.24 \mathrm{~cd}$ & $1.49 \mathrm{~d}$ & ND & ND & $3.15 b$ & $5.54 \mathrm{a}$ & 29 \\
\hline Total Cd & $0.09 \mathrm{c}$ & $0.07 \mathrm{c}$ & $0.14 b$ & $0.06 \mathrm{c}$ & $0.29 a$ & $0.25 a$ & $0.08 \mathrm{c}$ & $0.08 \mathrm{c}$ & 0.8 \\
\hline Total Cr & - & $11.04 \mathrm{a}$ & $8.53 b$ & $5.52 \mathrm{c}$ & BDL & BDL & $6.61 \mathrm{c}$ & $7.96 \mathrm{~b}$ & 100 \\
\hline Total Pb & - & $10.41 \mathrm{c}$ & $27.48 \mathrm{a}$ & $16.65 b$ & $20.72 b$ & $19.76 b$ & $11.22 \mathrm{c}$ & $11.71 \mathrm{c}$ & 50 \\
\hline Total Hg & - & $0.06 a$ & ND & ND & ND & ND & $0.03 b$ & $0.02 b$ & 0.5 \\
\hline Total Se & $0.27 \mathrm{c}$ & $0.85 \mathrm{a}$ & ND & ND & $0.44 \mathrm{c}$ & $0.34 \mathrm{c}$ & $0.41 \mathrm{c}$ & $0.41 \mathrm{c}$ & 0.7 \\
\hline Extractable B & $0.14 \mathrm{~d}$ & $0.09 \mathrm{~d}$ & $1.33 \mathrm{c}$ & $1.26 \mathrm{c}$ & $7.30 \mathrm{a}$ & $3.35 b$ & $0.11 \mathrm{~d}$ & $0.12 \mathrm{~d}$ & - \\
\hline Total Zn & $21.16 \mathrm{~d}$ & $18.53 d$ & $10.48 \mathrm{e}$ & $9.30 \mathrm{e}$ & $35.09 \mathrm{~b}$ & $26.80 \mathrm{c}$ & $34.47 \mathrm{~b}$ & $40.31 \mathrm{a}$ & 140 \\
\hline Total Mn & $21.43 \mathrm{e}$ & $41.98 c$ & $32.39 \mathrm{~d}$ & $33.89 \mathrm{~d}$ & $54.69 b$ & $87.74 a$ & $22.55 \mathrm{e}$ & $44.47 \mathrm{c}$ & - \\
\hline Total Ce & $4.03 \mathrm{f}$ & - & $12.73 \mathrm{e}$ & $116.19 b$ & $20.84 d$ & $197.89 \mathrm{a}$ & $11.06 \mathrm{e}$ & $87.92 \mathrm{c}$ & - \\
\hline Total La & $1.96 \mathrm{e}$ & - & $6.46 \mathrm{~d}$ & $70.80 \mathrm{~b}$ & $12.60 \mathrm{c}$ & $137.43 \mathrm{a}$ & $3.82 \mathrm{~d}$ & $53.95 b$ & - \\
\hline Total Sr & $8.38 \mathrm{c}$ & $12.57 \mathrm{c}$ & $15.73 c$ & $20.73 b$ & $14.45 \mathrm{c}$ & $29.91 \mathrm{a}$ & $8.19 d$ & $11.74 \mathrm{c}$ & - \\
\hline Total Ag & - & $0.02 \mathrm{~b}$ & $0.06 \mathrm{a}$ & $0.03 b$ & $\mathrm{BDL}$ & $\mathrm{BDL}$ & $0.07 \mathrm{a}$ & $0.03 \mathrm{~b}$ & - \\
\hline Total Ba & - & $33.00 \mathrm{a}$ & $13.33 \mathrm{c}$ & $13.14 \mathrm{c}$ & $8.82 \mathrm{~d}$ & $21.71 b$ & $4.30 \mathrm{e}$ & $28.55 \mathrm{a}$ & 200 \\
\hline
\end{tabular}

432 Note: Source of standard: *the new Dutch list [32]; Max: maximum treatment; within rows, means followed by a common letter are not 433 significantly different using LSD test at the 5\% level of significance. 


\section{Effects of PG organic application on boreholes and surface water}

435 Data for heavy metal contents in water were separated between the boreholes and

436 surface water (Table 7). This was to give a better data comparison to their respective

437 values before PG organic application. Concentrations of cytotoxic heavy metals (As,

$438 \mathrm{Cd}, \mathrm{Cr}, \mathrm{Pb}, \mathrm{Hg}$, and $\mathrm{Se}$ ) in water boreholes were generally significantly lower than

439 those in the surface water (Table 7). Their concentrations fluctuated with the time of

440 sampling. All values were lower than the target value stipulated in the Malaysian

441 Standard for Raw Drinking Water Quality [33]. Phytotoxic heavy metal (Zn, Mn, and

442 B) concentrations fluctuated with the time of sampling. The contents of these metals

443 in the boreholes were significantly lower than in the surface water. Their contents in

444 the borehole water were not significantly different with the baseline data and lower

445 than the target values in the Malaysian Standard for Raw Drinking Water Quality

446 [33]. The other metal concentrations in boreholes also fluctuated with the time of

447 sampling. Their concentrations in the boreholes were significantly lower than in the

448 surface water. The application of PG organic to the trial plot in Sungai Ular could

449 influence the metal concentrations in the boreholes but could not influence the metal

450 contents in the river due to the proximity of the trial plot. Any changes in metal

451 contents in the river were a direct contribution of the natural input and anthropogenic

452 input from the surrounding environment. Evidence from the data gathered in this

453 monitoring program showed that the application of PG organic did not accumulate

454 and contaminate the borehole water. 
Table 7 Heavy metals contents in boreholes and surface water before and after PG organic application.

\begin{tabular}{|c|c|c|c|c|c|c|c|c|c|c|c|}
\hline \multicolumn{2}{|c|}{ Heavy metals $(\mu \mathrm{g} / \mathrm{L})$} & \multirow{2}{*}{$\begin{array}{c}\text { Baseline } \\
(22-05-2015) \\
\\
\text { Surface } \\
\text { Water }\end{array}$} & \multicolumn{2}{|c|}{$\begin{array}{l}\text { After PG organic } \\
\text { application } \\
(22-01-2016)\end{array}$} & \multicolumn{2}{|c|}{$\begin{array}{c}\text { After PG organic } \\
\text { application Harvest } 1 \\
(17-09-2016)\end{array}$} & \multicolumn{2}{|c|}{$\begin{array}{c}\text { After PG organic } \\
\text { application } \\
\text { Harvest } 2 \\
(08-12-2016)\end{array}$} & \multicolumn{2}{|c|}{$\begin{array}{c}\text { After PG organic } \\
\text { application } \\
\text { Harvest } 3 \\
(10-05-2017)\end{array}$} & \multirow[t]{2}{*}{$\begin{array}{c}\text { *Target } \\
\text { value } \\
(\mu \mathrm{g} / \mathrm{L})\end{array}$} \\
\hline & Borehole & & Borehole & $\begin{array}{c}\text { Surface } \\
\text { Water }\end{array}$ & Borehole & $\begin{array}{c}\text { Surface } \\
\text { Water }\end{array}$ & Borehole & $\begin{array}{r}\text { Surface } \\
\text { Water }\end{array}$ & Borehole & $\begin{array}{r}\text { Surface } \\
\text { Water }\end{array}$ & \\
\hline As & 0.30 & 4.08 & 0.05 & 0.85 & 0.21 & 0.99 & 0.86 & 2.81 & 0.18 & 1.40 & 10 \\
\hline $\mathrm{Cd}$ & 0.01 & 0.17 & 0.02 & 1.04 & 0.04 & 0.42 & 0.04 & 0.03 & 0.05 & 0.02 & 0.3 \\
\hline $\mathrm{Cr}$ & - & - & 0.61 & 3.59 & 0.38 & 4.06 & 0.19 & 1.84 & 2.02 & 3.02 & 50 \\
\hline $\mathrm{Pb}$ & - & - & 0.39 & 3.56 & 0.70 & 4.52 & ND & ND & 7.27 & 0.68 & 10 \\
\hline $\mathrm{Hg}$ & - & - & 0.06 & 0.05 & ND & ND & ND & ND & 1.15 & 1.09 & 1 \\
\hline $\mathrm{Se}$ & 0.24 & 4.18 & 0.25 & 0.15 & 0.42 & 1.73 & 0.17 & 0.22 & 3.25 & 1.85 & 10 \\
\hline B & 34.83 & 272.73 & 18.82 & 24.76 & 11.31 & 50.63 & 7.31 & 19.60 & 18.20 & 49.67 & - \\
\hline $\mathrm{Zn}$ & 45.10 & 101.70 & 51.97 & 81.99 & 54.67 & 198.75 & 19.70 & 51.11 & 29.61 & 80.79 & 3000 \\
\hline Mn & 19.44 & 82.80 & 5.08 & 32.25 & 26.70 & 398.57 & 8.94 & 25.92 & 23.65 & 80.61 & 200 \\
\hline $\mathrm{Th}$ & 0.03 & 0.26 & 0.68 & 36.75 & 0.68 & 105.85 & 0.01 & 0.33 & 0.17 & 0.87 & - \\
\hline $\mathrm{Ce}$ & 0.11 & 0.38 & 10.80 & 226.73 & 0.34 & 43.83 & 0.16 & 1.36 & 5.37 & 5.23 & - \\
\hline $\mathrm{La}$ & 0.04 & 0.23 & 10.14 & 183.78 & 46.68 & 119.34 & 0.08 & 0.56 & 1.81 & 1.66 & - \\
\hline $\mathrm{Sr}$ & 22.32 & 725.65 & 27.13 & 16.44 & 0.00 & 1.59 & 24.08 & 9.90 & 62.64 & 58.37 & - \\
\hline $\mathrm{Ag}$ & - & - & 0.03 & 0.17 & 0.00 & 0.05 & 0.00 & 0.00 & ND & ND & - \\
\hline $\mathrm{Ba}$ & - & - & 99.77 & 102.13 & 79.70 & 163.48 & 35.87 & 53.44 & 90.49 & 168.62 & 50 \\
\hline
\end{tabular}

45@Note: ND: not detected; Source of standard: *Malaysian Standard for Raw Drinking Water Quality [33]; the new Dutch list [32]. 
461 Metal contents in plants and in corn grain in three harvests are presented in Tables 8,

462 respectively.

Table 8 Heavy metals contents of cultivated plantsand corn grain in Sungai Ular research plots.

\begin{tabular}{|c|c|c|c|c|c|c|c|}
\hline \multirow{3}{*}{$\begin{array}{l}\text { Heavy metals } \\
\text { (Plants)(mg/kg) }\end{array}$} & \multicolumn{6}{|c|}{ Sampling frequency } & \\
\hline & \multicolumn{2}{|c|}{ 27-09-2016 } & \multicolumn{2}{|c|}{$08-12-2016$} & \multicolumn{2}{|c|}{ 24-04-2017 } & \\
\hline & Control & $\operatorname{Max}$ & Control & $\operatorname{Max}$ & Control & Max & \\
\hline Total As & $0.68 \mathrm{a}$ & $0.62 a$ & ND & ND & NPG & 0.10 & \\
\hline Total Cd & $0.07 b$ & $0.09 b$ & $0.21 \mathrm{a}$ & $0.22 \mathrm{a}$ & NPG & $0.03 \mathrm{c}$ & \\
\hline Total $\mathrm{Pb}$ & $0.86 \mathrm{~b}$ & $0.64 \mathrm{c}$ & $2.22 \mathrm{a}$ & $0.98 b$ & NPG & $0.24 \mathrm{~d}$ & \\
\hline Total $\mathrm{Cr}$ & $0.38 b$ & $0.33 b$ & ND & ND & NPG & $1.94 \mathrm{a}$ & \\
\hline Total Hg & $0.02 \mathrm{a}$ & $0.01 \mathrm{a}$ & ND & ND & NPG & ND & \\
\hline Total Se & $0.18 \mathrm{a}$ & $0.13 b$ & $0.05 \mathrm{c}$ & $0.04 \mathrm{c}$ & NPG & $0.06 \mathrm{c}$ & \\
\hline Extractable B & $29.81 \mathrm{a}$ & $15.55 \mathrm{~b}$ & $26.64 a$ & $33.96 a$ & NPG & $6.25 \mathrm{c}$ & \\
\hline Total Zn & $142.33 \mathrm{a}$ & $71.47 \mathrm{~b}$ & $35.37 \mathrm{c}$ & $39.79 \mathrm{c}$ & NPG & $9.17 \mathrm{~d}$ & \\
\hline Total Mn & $15.59 \mathrm{~d}$ & $4.17 \mathrm{e}$ & $92.98 \mathrm{a}$ & $63.99 \mathrm{~b}$ & NPG & $49.64 c$ & \\
\hline Total Ce & $1.47 \mathrm{~b}$ & $2.08 b$ & $0.34 \mathrm{c}$ & $0.30 \mathrm{c}$ & NPG & $5.39 \mathrm{a}$ & \\
\hline Total La & $0.97 \mathrm{a}$ & $1.54 \mathrm{a}$ & $0.34 \mathrm{~b}$ & $0.35 b$ & NPG & $0.16 \mathrm{c}$ & \\
\hline Total Sr & $16.63 b$ & $9.21 \mathrm{c}$ & $58.49 \mathrm{a}$ & $68.06 \mathrm{a}$ & NPG & $11.18 \mathrm{c}$ & \\
\hline Total Th & $0.13 b$ & $0.12 \mathrm{a}$ & ND & ND & NPG & $0.08 \mathrm{c}$ & \\
\hline Total Ag & $0.02 \mathrm{a}$ & $0.00 \mathrm{~b}$ & ND & ND & NPG & ND & \\
\hline Total Ba & $2.21 \mathrm{c}$ & $1.11 \mathrm{~d}$ & $10.28 \mathrm{a}$ & $8.29 b$ & NPG & $1.08 \mathrm{~d}$ & \\
\hline \multirow[t]{2}{*}{$\begin{array}{l}\text { Heavy metals (Corn } \\
\text { grain) }(\mathrm{mg} / \mathrm{kg})\end{array}$} & \multicolumn{2}{|c|}{ 27-09-2016 } & \multicolumn{2}{|c|}{ 08-12-2016 } & \multicolumn{2}{|c|}{ 24-04-2017 } & $\begin{array}{l}{ }^{*} \mathrm{Limit} \\
\mathrm{mg} / \mathrm{kg}\end{array}$ \\
\hline & Control & $\operatorname{Max}$ & Control & $\operatorname{Max}$ & Control & $\operatorname{Max}$ & \\
\hline Total As & - & - & $0.02 \mathrm{c}$ & ND & $0.37 \mathrm{a}$ & $0.22 b$ & $<1$ \\
\hline Total Cd & - & - & 0.00 & $0.36 \mathrm{a}$ & $0.01 \mathrm{a}$ & $0.01 \mathrm{a}$ & $<1$ \\
\hline Total Pb & - & - & $0.07 \mathrm{c}$ & $0.30 \mathrm{a}$ & $0.44 \mathrm{a}$ & $0.30 \mathrm{a}$ & $<2$ \\
\hline Total $\mathrm{Cr}$ & - & - & $1.43 \mathrm{c}$ & ND & $3.17 b$ & $4.55 \mathrm{a}$ & - \\
\hline Total Hg & - & - & ND & ND & ND & ND & - \\
\hline Total Se & - & - & $0.01 \mathrm{~b}$ & $0.03 \mathrm{a}$ & $0.04 \mathrm{a}$ & $0.02 \mathrm{ab}$ & $<0.05$ \\
\hline Extractable B & - & - & $2.82 \mathrm{~b}$ & $2.24 b$ & $23.88 \mathrm{a}$ & $20.49 a$ & - \\
\hline Total Zn & - & - & $10.63 \mathrm{c}$ & $18.63 b$ & $40.91 \mathrm{a}$ & $38.12 \mathrm{a}$ & - \\
\hline Total Mn & - & - & $7.52 b$ & $5.67 \mathrm{c}$ & $6.69 b c$ & $9.91 \mathrm{a}$ & - \\
\hline Total Ce & - & - & $0.29 \mathrm{c}$ & $0.20 \mathrm{c}$ & $1.38 \mathrm{a}$ & $0.69 b$ & - \\
\hline Total La & - & - & $0.07 \mathrm{~d}$ & $0.23 c$ & $0.70 \mathrm{a}$ & $0.47 b$ & - \\
\hline Total Sr & - & - & $1.47 \mathrm{a}$ & $0.80 \mathrm{~d}$ & $1.07 \mathrm{~b}$ & $0.94 \mathrm{c}$ & - \\
\hline Total Th & - & - & 0.02 & ND & ND & ND & - \\
\hline Total Ag & - & - & ND & ND & ND & ND & - \\
\hline Total Ba & - & - & ND & ND & $1.06 \mathrm{a}$ & $0.97 \mathrm{a}$ & - \\
\hline
\end{tabular}

465 Note: ND: not detected; max:maximum treatment; NPG: no plant growing; source of 466 standard:*Malaysian Food Act [34] and Food Regulation [35]; within rows, means 467 followed by a common letter are not significantly different using LSD test at the 5\% 468 level of significance. 
469 Metal contents in the plants of the plot treated with PG organic were compared with

470 the control plot. The metal contents in plants were also compared with the standard

471 given in Kabata-Pendias [45] and compared with the Malaysian Food Act [34] and

472 Food Regulation [35] for grain.

473 Cytotoxic heavy metal (As, $\mathrm{Cd}, \mathrm{Cr}, \mathrm{Pb}, \mathrm{Hg}$ and $\mathrm{Se}$ ) contents in plants treated with $\mathrm{PG}$

474 organic were not significantly different or significantly lower than $(p<0.05)$ the

475 control. Phytotoxic metals (B, Zn, and $\mathrm{Mn}$ ) in plants treated with PG organic were

476 significantly lower or not significantly different compared to the control plants. These

477 metals were also micronutrients for plants; therefore, their high contents in the plants

478 are desirable. There was no significant difference in the contents of other metals

479 between the plants treated with PG organic and the control plants. There was no

480 indication of metals accumulating with season of sampling.

481 Cytotoxic heavy metals ( $\mathrm{As}, \mathrm{Cd}, \mathrm{Pb}, \mathrm{Cr}, \mathrm{Hg}$ and $\mathrm{Se}$ ) recorded a low value compared 482 to the limit stipulated in the Malaysian Food Act [34] and Food Regulation [35] 483 standards. Phytotoxic heavy metals B, Mn and $\mathrm{Zn}$ in the plots treated with PG organic 484 were significantly higher than the control, which suggested that PG organic 485 application can contribute to a higher micronutrient supply to the plant. 486 Concentrations of the other metals were low, and in general, the contents of metals in 487 grain from plots treated with PG organic were significantly lower $(\mathrm{p}<0.05)$ than the 488 control. Data of heavy metals in grains showed that there was no accumulation of 489 metals and lower contents of heavy metals compared to the standard. Therefore, PG 490 organic is safe for use as a soil conditioner. 
492 The uptake of heavy metals in grain is shown by its biological accumulation 493 coefficient (BAC), and the accumulation and contamination of heavy metals in soil 494 are shown by its geo-accumulation Index (I-geo), contamination factor (CF) and PLI 495 in Table 9. 496 Table 9 Biological accumulation coefficients of heavy metals in grains and soil
contamination levels following treatment with PG organic at Sungai Ular.

\begin{tabular}{|c|c|c|c|}
\hline Metal & & $\begin{array}{l}\text { SungaiUlar UPM } \\
\text { plot }\end{array}$ & Notes \\
\hline \multirow[t]{3}{*}{ As } & BAC & 0.19 & Moderate \\
\hline & I-geo & -2.89 & Uncontaminated \\
\hline & $\mathrm{CF}$ & 0.20 & low $\mathrm{CF}$ \\
\hline \multirow[t]{3}{*}{$\mathrm{Cd}$} & $\mathbf{B A C}$ & 0.75 & Moderate \\
\hline & I-geo & -1.38 & Uncontaminated \\
\hline & $\mathrm{CF}$ & 0.58 & low $\mathrm{CF}$ \\
\hline \multirow[t]{3}{*}{$\mathrm{Pb}$} & $\mathbf{B A C}$ & 0.05 & Low \\
\hline & I-geo & -0.36 & Uncontaminated \\
\hline & $\mathrm{CF}$ & 0.45 & low $\mathrm{CF}$ \\
\hline \multirow[t]{3}{*}{$\mathrm{Cr}$} & $\mathbf{B A C}$ & 0.03 & Low \\
\hline & I-geo & -3.86 & Uncontaminated \\
\hline & $\mathrm{CF}$ & 0.10 & low $\mathrm{CF}$ \\
\hline \multirow[t]{3}{*}{$\mathrm{Se}$} & $\mathbf{B A C}$ & 0.00 & Weak \\
\hline & I-geo & 0.00 & Uncontaminated \\
\hline & $\mathrm{CF}$ & 0.00 & low $\mathrm{CF}$ \\
\hline \multirow[t]{3}{*}{$\mathrm{Zn}$} & $\mathbf{B A C}$ & 0.61 & Moderate \\
\hline & I-geo & -3.08 & Uncontaminated \\
\hline & $\mathrm{CF}$ & 0.18 & low $\mathrm{CF}$ \\
\hline \multirow[t]{3}{*}{$\mathrm{Mn}$} & $\mathbf{B A C}$ & 1.76 & Active \\
\hline & Igeo & -4.29 & Uncontaminated \\
\hline & $\mathrm{CF}$ & 0.07 & low $\mathrm{CF}$ \\
\hline \multirow[t]{4}{*}{ B } & BAC & 20.88 & Active \\
\hline & Igeo & -6.87 & Uncontaminated \\
\hline & $\mathrm{CF}$ & 0.01 & low $\mathrm{CF}$ \\
\hline & PLI & 0.25 & Not polluted \\
\hline
\end{tabular}

510 The BAC factors $>1$ indicate that the plant species has the ability to store metals from

511 the soil in the shoots [46]. In contrast, BAC factors $<1$ indicates that the plant species

512 do not store metals from the soil in the shoots. The corn grain in Sungai Ular showed 
513 BAC values of less than 1, except for B and Mn, which meant that all metals do not

514 have the potential to be accumulated in the plant. Boron and Mn have a BAC of more

515 than 1, indicating very active uptake. These metals are micronutrients normally used 516 by plants for their growth.

517 The I-geo index is a quantitative measure of the degree of pollution in aquatic

518 sediments or soils. It consists of seven grades ranging from unpolluted to a very

519 extremely polluted environment. The I-geo index showed that all heavy metals in

520 Sungai Ular fall in grade 0 (Table 9). This suggests that the BRIS soils at the research

521 plot at Sungai Ular were not contaminated.

522 The PLI was calculated from the contamination factors $(\mathrm{CF})$. This $\mathrm{CF}$ is the quotient

523 obtained by dividing the concentration of each metal by its background concentration.

524 The PLI values of the plot were calculated by obtaining the n-root from the n-CFs that

525 were obtained for all metals from each plot. Pollution severity and its variation among

526 the trial plots were determined with the use of the PLI. This index is a quick tool in

527 order to compare the pollution statuses of different places. A PLI value $=0$ is

528 'Perfection', PLI=1 indicates baseline levels of pollutants in the examined sample, and

529 PLI $>1$ denotes a steady increase of pollution in the specimen $[40,47]$. The results of

530 the present study showed that the CF values of all of the metals in the study area were

531 low $(<1)$ indicating that there was no increase of heavy metals in the soil. The PLI

532 values for all heavy metals in Sungai Ular were very low, indicating that the soils

533 were not polluted by the application of PG organic. 


\section{Radiological Environmental Monitoring Program}

\section{Quality control of the analysis data}

536 The measured radioactivity concentrations for ${ }^{226} \mathrm{Ra}\left({ }^{238} \mathrm{U}\right.$ series $),{ }^{228} \mathrm{Ra}\left({ }^{232} \mathrm{Th}\right.$ series $)$

537 and ${ }^{40} \mathrm{~K}$ for the gamma spectrometry system were in the range of the $95 \%$ confidence 538 level, as proposed by the IAEA for reference material CRM-375 (Table 10).

539 Moreover, the MDA analysis indicated that the lower limits of detection for ${ }^{226} \mathrm{R}$, $540 \quad{ }^{228} \mathrm{Ra}$ and ${ }^{40} \mathrm{~K}$ were $0.7,0.2$ and $1.2 \mathrm{~Bq} \mathrm{~kg}^{-1}$, respectively. Based on both analyses, it 541 can be judged that the gamma spectrometry system was in good condition, and the 542 results were acceptable during the analysis period.

\section{$543 \quad$ Natural radioactivity concentrations in soil}

544 The analysis revealed that the radioactivity concentrations of ${ }^{226} \mathrm{Ra},{ }^{228} \mathrm{Ra}$, and ${ }^{40} \mathrm{~K}$ in 545 all samples (Table 10) were found to be much lower than the average concentrations 546 in Malaysia's soil $\left({ }^{226} \mathrm{Ra}=67.0 \mathrm{~Bq} \mathrm{~kg}{ }^{-1} ;{ }^{226} \mathrm{Ra}=82.0 \mathrm{~Bq} \mathrm{~kg}{ }^{-1} ;{ }^{238} \mathrm{U}=66 \mathrm{~Bq} \mathrm{~kg}^{-1}\right.$; and

$547{ }^{232} \mathrm{Th}=82.0 \mathrm{~Bq} \mathrm{~kg}^{-1}$ ), as reported by the United Nations Scientific Committee on the 548 Effect of Atomic Radiation [48].

549 The comparison between the previous studies performed in Malaysia showed that the 550 results obtained in this study were in the normal range, as shown in Table 10 . The 551 differences in natural radionuclide concentrations in soil are related to several factors, 552 such as geographical factors and geological conditions, as well as to the extent that 553 fertilizer is used on the land in the agricultural industry [49].

554 In addition, the findings showed that ${ }^{40} \mathrm{~K}$ had the highest concentrations compared to $555{ }^{226} \mathrm{Ra}$ and ${ }^{228} \mathrm{Ra}$. Potassium (or ${ }^{40} \mathrm{~K}$ ) is a mobile nutrient that tends to move and 556 accumulate on the soil surface [50]. 

soil samples obtained in this study with other literature.

\begin{tabular}{|c|c|c|c|c|c|}
\hline \multirow[t]{2}{*}{ Season } & \multirow[t]{2}{*}{ Sample ID } & & \multicolumn{3}{|c|}{ Activity Concentration $(\mathrm{Bq} / \mathrm{kg})$} \\
\hline & & & ${ }^{226} \mathrm{Ra}$ & ${ }^{228} \mathrm{Ra}$ & ${ }^{40} \mathrm{~K}$ \\
\hline \multirow{10}{*}{$2^{\text {nd }}$ Season } & \multirow[t]{2}{*}{ Kenaf-Soil-Control } & Range & $13.8-17.6$ & $15.7-16.8$ & $44.5-47.0$ \\
\hline & & Average & $15.7 \pm 2.7$ & $16.3 \pm 0.8$ & $45.7 \pm 1.8$ \\
\hline & \multirow[t]{2}{*}{ Kenaf-Soil-Condi } & Range & $14.0-16.0$ & $18.0-19.9$ & $46.7-49.7$ \\
\hline & & Average & $15.0 \pm 1.4$ & $19.0 \pm 1.4$ & $48.2 \pm 2.1$ \\
\hline & \multicolumn{2}{|c|}{ ANOVA Analysis } & $0.77^{\mathrm{ns}}$ & $0.13^{\mathrm{ns}}$ & $0.12^{\mathrm{ns}}$ \\
\hline & \multirow{2}{*}{$\begin{array}{l}\text { Guinea grass-Soil- } \\
\text { Control }\end{array}$} & Range & $14.4-16.8$ & $15.6-17.1$ & $59.6-72.8$ \\
\hline & & Average & $15.6 \pm 1.7$ & $16.3 \pm 1.1$ & $66.2 \pm 9.3$ \\
\hline & \multirow[t]{2}{*}{$\begin{array}{l}\text { Guinea grass-Soil-PG } \\
\text { organic }\end{array}$} & Range & $15.4-17.5$ & $27.6-34.7$ & $54.8-65.4$ \\
\hline & & Average & $16.5 \pm 1.5$ & $31.2 \pm 5.0$ & $60.1 \pm 7.5$ \\
\hline & \multicolumn{2}{|c|}{ ANOVA Analysis } & $0.70^{\mathrm{ns}}$ & $0.06^{\mathrm{ns}}$ & $1.00^{\mathrm{ns}}$ \\
\hline \multirow{10}{*}{$3^{\text {rd }}$ Season } & \multirow[t]{2}{*}{ Kenaf-Soil-Control } & Range & $13.3-14.7$ & $16.5-17.0$ & $49.3-55.5$ \\
\hline & & Average & $14.0 \pm 1.0$ & $16.8 \pm 0.4$ & $52.4 \pm 4.4$ \\
\hline & \multirow[t]{2}{*}{$\begin{array}{l}\text { Kenaf-Soil-PG } \\
\text { organic }\end{array}$} & Range & $16.7-17.6$ & $19.2-21.0$ & $47.8-57.7$ \\
\hline & & Average & $17.1 \pm 0.6$ & $20.1 \pm 1.3$ & $52.8 \pm 7.0$ \\
\hline & \multicolumn{2}{|c|}{ ANOVA Analysis } & $0.07^{\mathrm{ns}}$ & $0.07^{\mathrm{ns}}$ & $0.96^{\mathrm{ns}}$ \\
\hline & \multirow[t]{2}{*}{$\begin{array}{l}\text { Guinea } \\
\text { Control }\end{array}$} & Range & $12.2-14.8$ & $16.0-16.7$ & $47.7-53.2$ \\
\hline & & Average & $13.5 \pm 1.8$ & $16.3 \pm 0.4$ & $50.4 \pm 3.9$ \\
\hline & \multirow[t]{2}{*}{$\begin{array}{l}\text { Guinea grass-Soil-PG } \\
\text { organic }\end{array}$} & Range & $13.7-15.1$ & $16.8-18.1$ & $60.6-61.4$ \\
\hline & & Average & $14.4 \pm 1.0$ & $17.6 \pm 0.7$ & $61.0 \pm 0.6$ \\
\hline & \multicolumn{2}{|c|}{ ANOVA Analysis } & $0.60^{\mathrm{ns}}$ & $0.05^{*}$ & $0.06^{\mathrm{ns}}$ \\
\hline \multicolumn{3}{|c|}{ Malaysia’s Soil [48] } & 67.0 & 82.0 & 310 \\
\hline \multicolumn{3}{|c|}{ Palm Oil Plantation, Malaysia [51] } & $21.5 \pm 8.4$ & $29.2 \pm 8.9$ & $56.8 \pm 36.3$ \\
\hline \multicolumn{3}{|c|}{ Paddy Plantation, Malaysia [52] } & $83.6 \pm 40.4$ & $108.1 \pm 28.4$ & $403.8 \pm 224.8$ \\
\hline \multicolumn{3}{|c|}{ Kuala Krai, Kelantan [53] } & $40.2-264.0$ & $29.2-312.9$ & $491.1-1184.2$ \\
\hline
\end{tabular}

55Note: ns: not significant; * and **: significant at $\mathrm{p} \leq 0.05$ and $\mathrm{p} \leq 0.01$, respectively. 
561 The concentrations of ${ }^{40} \mathrm{~K}$ in soil do not contribute significantly to the total

562 radioactive concentration in soil because ${ }^{40} \mathrm{~K}$ is not from the uranium or thorium

563 decay series [53]. Potassium-40 exists in nature, but the activity concentration may

564 increase due to the use of fertilizer in agriculture.

565 Even though there were variations in the concentrations of ${ }^{226} \mathrm{Ra},{ }^{228} \mathrm{Ra}$ and ${ }^{40} \mathrm{~K}$ in soil

566 before and after the application of PG organic for each season, the statistical analysis

567 (ANOVA) revealed that there were no significant differences $(\mathrm{p}>0.05)$ in the natural

568 radionuclide concentrations due to the PG organic treatment. Based on this finding, it

569 can be concluded that the addition of PG organic as a soil conditioner for BRIS soil

570 did not increase radionuclides in soil.

\section{$571 \quad$ Natural radioactivity concentrations in water}

572 The activity concentrations of ${ }^{226} \mathrm{Ra},{ }^{228} \mathrm{Ra}$ and ${ }^{40} \mathrm{~K}$ were different for each location

573 (Table 11). For example, the activity concentration of ${ }^{228} \mathrm{Ra}$ for both seasons ranged 574 from 0.3 to $3.9 \mathrm{~Bq} / \mathrm{L}$ and 0.6 to $3.9 \mathrm{~Bq} / \mathrm{L}$, respectively. Even though the 575 concentrations of natural radionuclides in samples look different for each sampling 576 point (BH1 to $\mathrm{BH} 5)$, the statistical analysis revealed that there were no significant 577 differences $(\mathrm{p}>0.05)$ in ${ }^{226} \mathrm{Ra},{ }^{228} \mathrm{Ra}$ and ${ }^{40} \mathrm{~K}$ concentrations in water for both seasons.

578 The activity concentrations of ${ }^{226} \mathrm{Ra},{ }^{228} \mathrm{Ra}$ and ${ }^{40} \mathrm{~K}$ in water recorded from this study 579 were lower than the levels reported by Almayahi et al. [41] in water samples sampled 580 along the Northern Peninsula of Malaysia. 
Table 11 Activity concentrations of ${ }^{226} \mathrm{Ra},{ }^{228} \mathrm{Ra}$ and ${ }^{40} \mathrm{~K}$ in water obtained from studied location.

\begin{tabular}{|c|c|c|c|c|c|}
\hline \multirow[t]{2}{*}{ Season } & \multirow[t]{2}{*}{ Sample ID } & & \multicolumn{3}{|c|}{ Activity Concentration $(\mathrm{Bq} / \mathrm{L})$} \\
\hline & & & ${ }^{226} \mathrm{Ra}$ & ${ }^{228} \mathrm{Ra}$ & ${ }^{40} \mathrm{~K}$ \\
\hline \multirow{16}{*}{$2^{\text {nd }}$ Season } & \multirow[t]{2}{*}{ BH-1 } & Range & $0.5-0.9$ & $1.1-3.9$ & $6.9-8.0$ \\
\hline & & Average & $0.7 \pm 0.3$ & $2.5 \pm 2.0$ & $7.4 \pm 0.8$ \\
\hline & \multirow[t]{2}{*}{$\mathrm{BH}-2$} & Range & $0.4-0.5$ & $0.9-1.1$ & $1.8-9.8$ \\
\hline & & Average & $0.5 \pm 0.1$ & $1.0 \pm 0.1$ & $5.8 \pm 5.6$ \\
\hline & \multirow[t]{2}{*}{$\mathrm{BH}-3$} & Range & BDL - 0.3 & $0.4-0.6$ & $1.4-1.8$ \\
\hline & & Average & $0.3 \pm 0.0$ & $0.5 \pm 0.1$ & $1.6 \pm 0.3$ \\
\hline & \multirow[t]{2}{*}{ BH-4 } & Range & $0.3-0.5$ & $0.7-0.8$ & $0.4-7.2$ \\
\hline & & Average & $0.4 \pm 0.2$ & $0.8 \pm 0.1$ & $3.4 \pm 5.4$ \\
\hline & \multirow[t]{2}{*}{ BH-5 } & Range & BDL & $0.3-0.6$ & $3.3-5.1$ \\
\hline & & Average & DBL & $0.5 \pm 0.2$ & $4.2 \pm 1.3$ \\
\hline & \multicolumn{2}{|c|}{ Average for BH } & 0.4 & 1.1 & 4.5 \\
\hline & \multirow[t]{2}{*}{ SW-1 } & Range & BDL - 0.3 & $0.6-0.9$ & $2.5-2.9$ \\
\hline & & Average & BDL & $0.8 \pm 0.2$ & $2.7 \pm 0.3$ \\
\hline & \multirow[t]{2}{*}{ SW-2 } & Range & $0.3-0.7$ & $1.3-1.8$ & $2.9-6.5$ \\
\hline & & Average & $0.5 \pm 0.3$ & $1.5 \pm 0.4$ & $4.7 \pm 2.6$ \\
\hline & \multicolumn{2}{|c|}{ Average for SW } & 0.4 & 1.2 & 3.7 \\
\hline \multirow{18}{*}{$3^{\text {rd }}$ Season } & \multirow[t]{2}{*}{$\mathrm{BH}-1$} & Range & BDL - 0.3 & $1.6-3.2$ & $6.5-11.6$ \\
\hline & & Average & $0.2 \pm 0.1$ & $2.4 \pm 1.1$ & $9.0 \pm 3.6$ \\
\hline & \multirow[t]{2}{*}{ BH-2 } & Range & $0.3-0.4$ & $0.6-2.3$ & $7.6-8.0$ \\
\hline & & Average & $0.3 \pm 0.0$ & $1.5 \pm 1.2$ & $7.8 \pm 0.3$ \\
\hline & \multirow[t]{2}{*}{$\mathrm{BH}-3$} & Range & $0.3-0.4$ & $0.9-1.7$ & $2.2-3.6$ \\
\hline & & Average & $0.4 \pm 0.0$ & $1.3 \pm 0.5$ & $2.9 \pm 1.0$ \\
\hline & \multirow[t]{2}{*}{ BH-4 } & Range & $0.4-0.6$ & $1.8-2.0$ & $5.4-5.8$ \\
\hline & & Average & $0.5 \pm 0.2$ & $1.9 \pm 0.1$ & $5.6 \pm 0.3$ \\
\hline & \multirow[t]{2}{*}{ BH-5 } & Range & $\mathrm{BDL}$ & $0.7-1.1$ & $2.2-5.8$ \\
\hline & & Average & $0.1 * \pm 0.0$ & $0.9 \pm 0.3$ & $4.0 \pm 2.6$ \\
\hline & \multicolumn{2}{|c|}{ Average for BH } & 0.3 & 1.6 & 5.9 \\
\hline & \multirow[t]{2}{*}{ SW-1 } & Range & $0.3-0.4$ & $1.7-2.9$ & $6.1-10.1$ \\
\hline & & Average & $0.4 \pm 0.0$ & $2.3 \pm 0.9$ & $8.1 \pm 2.8$ \\
\hline & \multirow[t]{2}{*}{ SW-2 } & Range & BDL & $0.5-1.3$ & $4.7-5.8$ \\
\hline & & Average & BDL & $0.9 \pm 0.6$ & $5.2 \pm 0.8$ \\
\hline & \multicolumn{2}{|c|}{ Average for SW } & 0.3 & 1.5 & 6.6 \\
\hline & \multicolumn{2}{|c|}{$\begin{array}{l}\text { ANOVA analysis for BH for } \\
\text { both seasons }\end{array}$} & $0.31^{\mathrm{ns}}$ & $0.27^{\mathrm{ns}}$ & $0.38^{\mathrm{ns}}$ \\
\hline & \multicolumn{2}{|c|}{$\begin{array}{l}\text { ANOVA analysis for SW } \\
\text { for both seasons }\end{array}$} & $1.00^{\mathrm{ns}}$ & $0.62^{\mathrm{ns}}$ & $0.24^{\mathrm{ns}}$ \\
\hline \multicolumn{3}{|c|}{16 water sample at Norther Peninsular Malaysia [41] } & $0.9-7.0$ & $0.6-8.6$ & $53.0-222.0$ \\
\hline \multicolumn{3}{|c|}{$\begin{array}{l}\text { Tap, stream, lake, river water at Seberang Perai, } \\
\text { Malaysia [54] }\end{array}$} & $3.3-4.3$ & $0.9-2.2$ & $134.8-172.4$ \\
\hline 10 drinking wate & ples at Malaj & [55] & $0.02-0.09$ & $0.02-0.08$ & $1.7-8.8$ \\
\hline
\end{tabular}

58Note: ND: Not Detected; ns: not significant; Source of standard: *The reported value is 586elow the detection limit; Lower limit detection (LLD): ${ }^{226} \mathrm{Ra}(0.3 \mathrm{~Bq} / \mathrm{L}) ;{ }^{228} \mathrm{Ra}(0.1$ $58 \mathrm{~Bq} / \mathrm{L}) ;{ }^{40} \mathrm{~K}(1.2 \mathrm{~Bq} / \mathrm{L})$. 
588 This finding also suggested that there was no leaching of the radionuclides from soil

589 to groundwater. The activity concentrations of ${ }^{226} \mathrm{Ra},{ }^{228} \mathrm{Ra}$ and ${ }^{40} \mathrm{~K}$ in groundwater

590 depended greatly on the type of minerals derived from aquifer rocks and soil

591 compounds [56]. In addition, the surface water analysis from the nearest river also

592 suggested that there is no accumulation (discharge) of natural radionuclides in the

593 water due to the application of PG organic. Based on this finding, it can be concluded

594 that the applications of PG organic did not contribute to groundwater and surface

595 water contamination during the studied period.

\section{$596 \quad$ Natural radioactivity concentrations in plants}

597 There was a significant difference in the activity concentration for ${ }^{40} \mathrm{~K}$ in Guinea grass

598 ( $2^{\text {nd }}$ season) and kenaf $\left(3^{\text {rd }}\right.$ season $)$ between the control sample and treated sample

599 (PG organic sample) (Table 12). The average concentrations of ${ }^{40} \mathrm{~K}$ in the control

600 samples for Guinea grass leaf ( $2^{\text {nd }}$ season $)$ and kenaf stem $\left(3^{\text {rd }}\right.$ season $)$ were recorded

601 to be $19.9 \pm 8.5$ and $44.8 \pm 3.1 \mathrm{~Bq} / \mathrm{kg}$, respectively. On the other hand, the average

602 activity concentrations of ${ }^{40} \mathrm{~K}$ in the samples treated with PG organic (Guinea grass

603 leaf and kenaf stem) increased to $225.3 \pm 1.2$ and $111.7 \pm 1.2 \mathrm{~Bq} / \mathrm{kg}$, respectively. In

604 addition, most plant samples contain higher ${ }^{40} \mathrm{~K}$ concentrations compared to the

605 concentrations of ${ }^{40} \mathrm{~K}$ in soil. These findings are in agreement with previous studies

$606 \quad[52,57-60]$.

607 This finding is not the expected result, since the activity concentrations of ${ }^{40} \mathrm{~K}$ in the

608 soil samples treated with PG organic were much lower than the concentrations of ${ }^{40} \mathrm{~K}$

609 in the plant samples. 
611 Table 12 The radioactivity concentrations of ${ }^{226} \mathbf{R a},{ }^{228} \mathrm{Ra}$ and ${ }^{40} \mathrm{~K}$ in plant 612 samples.

\begin{tabular}{|c|c|c|c|c|c|c|}
\hline \multirow[t]{2}{*}{ Season } & \multicolumn{3}{|c|}{ Sample ID } & \multicolumn{3}{|c|}{ Activity Concentration $(\mathrm{Bq} / \mathrm{kg})$} \\
\hline & & & & ${ }^{226} \mathrm{Ra}$ & ${ }^{228} \mathrm{Ra}$ & ${ }^{40} \mathrm{~K}$ \\
\hline \multirow{10}{*}{$2^{\text {nd }}$ Season } & \multirow{2}{*}{\multicolumn{2}{|c|}{ Kenaf-stem-Control }} & Range & $8.3-8.5$ & $1.1-1.5$ & $116.8-146.4$ \\
\hline & & & Average & $8.4 \pm 0.1$ & $1.3 \pm 0.3$ & $131.6 \pm 20.9$ \\
\hline & \multirow{2}{*}{\multicolumn{2}{|c|}{ Kenaf-stem-PG organic }} & Range & $10.2-18.5$ & $0.3-0.7$ & $192.9-321.8$ \\
\hline & & & Average & $10.6 \pm 11.3$ & $0.5 \pm 0.3$ & $257.3 \pm 91.1$ \\
\hline & \multicolumn{3}{|c|}{ ANOVA Analysis } & $0.19^{\mathrm{ns}}$ & $0.10^{\mathrm{ns}}$ & $0.20^{\mathrm{ns}}$ \\
\hline & \multirow{2}{*}{$\begin{array}{l}\text { Guinea } \\
\text { Control }\end{array}$} & grass-leaf- & Range & $1.4-1.9$ & $0.1-0.3$ & $13.9-25.9$ \\
\hline & & & Average & $1.6 \pm 0.4$ & $0.2 \pm 0.2$ & $19.9 \pm 8.5$ \\
\hline & \multirow{2}{*}{$\begin{array}{l}\text { Guinea } \\
\text { organic }\end{array}$} & grass-leaf-PG & Range & $1.8-1.9$ & $0.1-0.6$ & $224.4-226.2$ \\
\hline & & & Average & $1.9 \pm 0.0$ & $0.4 \pm 0.3$ & $225.3 \pm 1.2$ \\
\hline & & ANOVA Analy & & $0.51^{\mathrm{ns}}$ & $0.57^{\mathrm{ns}}$ & $0.0009^{* *}$ \\
\hline \multirow{10}{*}{$3^{\text {rd }}$ Season } & \multirow{2}{*}{\multicolumn{2}{|c|}{ Kenaf-stem-Control }} & Range & $7.2-12.4$ & $0.6-1.2$ & $42.7-47.0$ \\
\hline & & & Average & $9.8 \pm 3.7$ & $0.9 \pm 0.4$ & $44.8 \pm 3.1$ \\
\hline & \multirow{2}{*}{\multicolumn{2}{|c|}{ Kenaf-stem-PG organic }} & Range & $5.0-9.5$ & $0.1-0.4$ & $110.9-112.5$ \\
\hline & & & Average & $7.2 \pm 3.2$ & $0.2 \pm 0.2$ & $111.7 \pm 1.2$ \\
\hline & \multicolumn{3}{|c|}{ ANOVA Analysis } & $0.54^{\mathrm{ns}}$ & $0.16^{\mathrm{ns}}$ & $0.001^{* *}$ \\
\hline & \multirow{2}{*}{$\begin{array}{l}\text { Guinea } \\
\text { Control }\end{array}$} & grass-leaf- & Range & $4.8-8.5$ & $1.2-2.7$ & $321.0-384.4$ \\
\hline & & & Average & $6.7 \pm 2.6$ & $1.9 \pm 1.1$ & $352 \pm 44.9$ \\
\hline & \multirow[t]{2}{*}{$\begin{array}{l}\text { Guinea } \\
\text { organic }\end{array}$} & garss-leaf-PG & Range & $2.9-5.1$ & $0.4-0.5$ & $204.9-227.6$ \\
\hline & & & Average & $4.0 \pm 1.6$ & $0.4 \pm 0.1$ & $216.2 \pm 16.0$ \\
\hline & \multicolumn{3}{|c|}{ ANOVA Analysis } & $0.34^{\mathrm{ns}}$ & $0.18^{\mathrm{ns}}$ & $0.06^{\mathrm{ns}}$ \\
\hline \multicolumn{4}{|c|}{ Vegetables (Malaysia) [57] } & $1.3-7.8^{\#}$ & $0.4-4.1^{\# \#}$ & - \\
\hline \multicolumn{4}{|c|}{ Vegetable leaves (Malaysia) [60] } & $0.6-5.64$ & - & $398.9-1072.6$ \\
\hline \multicolumn{4}{|c|}{ Corn (Malaysia) [61] } & $0.1-19.2$ & $0.1-3.2$ & $26.1-129.0$ \\
\hline \multicolumn{4}{|c|}{ Paddy grain (Malaysia) [52] } & $0.5-2.8$ & $0.5-1.6$ & $43.5-108.5$ \\
\hline \multicolumn{4}{|c|}{ Vegetables (Iraq) [59] } & $4.0-7.0^{\#}$ & $2.2-10.6^{\# \#}$ & $109.0-319.2$ \\
\hline
\end{tabular}

Wlbae: ${ }^{\#}$ Assume as ${ }^{226} \mathrm{Ra}\left({ }^{238} \mathrm{U}\right.$ decay series) in secular equilibrium; ${ }^{\#}$ Assume as ${ }^{228} \mathrm{Ra}\left({ }^{232} \mathrm{Th}\right.$ 6łday series) in secular equilibrium. ns: not significant; * and **: significant at $\mathrm{p} \leq 0.05$ and $\mathrm{p}$ ⿶16.01, respectively.

616 
617 This finding suggests that the increase in the ${ }^{40} \mathrm{~K}$ concentration in plants (compared to

618 the soil) might be contributed by other or additional sources, such as fertilizers,

619 pesticides or herbicides rather than PG organic. It should be noted that the uptake 620 mechanism will differ for each plant species. Several factors, such as the kinetic 621 parameters of plants to absorb specific radionuclides, metabolic behavior as well as

622 plant tolerance for a specific radionuclide will influence the uptake of radionuclides 623 by plants [62]. In addition, International Atomic Energy Agency, IAEA [63] reported 624 that the level of radioactivity concentrations for ${ }^{226} \mathrm{Ra}$ and ${ }^{238} \mathrm{U}$ in NPK fertilizer can 625 reach up to 450 and $1280 \mathrm{~Bq} \mathrm{~kg}^{-1}$, respectively. Therefore, further investigation is 626 recommended to verify the sources that contribute to the increase of ${ }^{40} \mathrm{~K}$ in plants.

\section{Radiological hazard index and soil-to-plant transfer factor}

628 A radium equivalent $\left(\mathrm{Ra}_{\mathrm{eq}}\right)$ is defined as the radiation hazard index $(\mathrm{RHI})$, which is 629 used to assess the radiation hazard due to the natural radionuclides. The calculated $630 \mathrm{Ra}_{\mathrm{eq}}$ for soil was much lower than the $370 \mathrm{~Bq} \mathrm{~kg}^{-1}$ recommended limit of $\mathrm{Ra}_{\mathrm{eq}}$ in soil 631 (Table 13). For non-hazardous materials, the calculated $\mathrm{Ra}_{\mathrm{eq}}$ should not exceed a 632 maximum value of $370 \mathrm{~Bq} \mathrm{~kg}^{-1}$ for soil [64]. Therefore, the radiological concern due 633 to the ${ }^{226} \mathrm{Ra},{ }^{228} \mathrm{Ra}$ and ${ }^{40} \mathrm{~K}$ in soil can be ignored; hence, $\mathrm{PG}$ organic is suitable for 634 agriculture applications. The TFs of ${ }^{226} \mathrm{Ra},{ }^{228} \mathrm{Ra},{ }^{238} \mathrm{U},{ }^{232} \mathrm{Th}$ and ${ }^{40} \mathrm{~K}$ obtained in this 635 study were comparable to those observed in several types of plants from other studies

636 (Table 13). The highest radionuclide TF was ${ }^{40} \mathrm{~K}$, which ranged from 0.85 to 6.98.

637 Minor dissimilarities of the TF among the samples were perhaps due to transport 638 processes as well as different absorption capacities of the vegetables itself [65]. It may 639 also depend on the type of soil, soil texture, clay content, $\mathrm{pH}$ and organic matter 640 content [66]. 
Table 13 Radium equivalent and soil-to-plant transfer factor obtained in this study.

\begin{tabular}{|c|c|c|c|c|c|c|c|c|}
\hline \multirow[t]{2}{*}{ Season } & \multirow[t]{2}{*}{ Sample } & \multirow[t]{2}{*}{$\mathrm{Ra}_{\mathrm{eq}}$} & \multicolumn{3}{|c|}{$\begin{array}{l}\text { Transfer factor } \\
\text { soil-to-plants }\end{array}$} & & \multirow[t]{2}{*}{ Note } & \multirow{2}{*}{$\begin{array}{l}643 \\
644\end{array}$} \\
\hline & & & ${ }^{226} \mathrm{Ra}$ & ${ }^{228} \mathrm{Ra}$ & ${ }^{40} \mathrm{~K}$ & & & \\
\hline \multirow{7}{*}{$2^{\text {nd }}$ season } & & $\mathrm{Bqkg}^{-1}$ & & & & & \multirow{5}{*}{ This research } & \multirow{5}{*}{645} \\
\hline & Kenaf-Soil-Control & 43.2 & 0.54 & 0.08 & 2.88 & & & \\
\hline & Kenaf-Soil-PG organic & 46.6 & 0.71 & 0.03 & 5.34 & & & \\
\hline & Guinea grass-Soil-Control & 44.7 & 0.10 & 0.01 & 0.30 & & & \\
\hline & Guinea grass -Soil-PG organic & 67.0 & 0.12 & 0.01 & 3.75 & & & \\
\hline & Kenaf-Soil-Control & 42.7 & 0.70 & 0.05 & 0.85 & & \multirow{4}{*}{ This research } & 646 \\
\hline & Kenaf-Soil-PG organic & 50.7 & 0.42 & 0.01 & 2.12 & & & \\
\hline \multirow[t]{2}{*}{$3^{\text {rd }}$ season } & Guinea grass -Soil-Control & 41.3 & 0.50 & 0.12 & 6.98 & & & \\
\hline & Guinea grass -Soil-PG organic & 45.0 & 0.28 & 0.02 & 3.54 & & & 647 \\
\hline \multicolumn{2}{|c|}{ Rice (Malaysia) } & - & $0.04-0.20$ & $0.02-0.15$ & $0.09-4.14$ & [67] & & \multirow{5}{*}{648} \\
\hline \multicolumn{2}{|c|}{ Rice (Malaysia) } & $9.9-27.7$ & $0.01-0.40$ & $0.01-0.60$ & $0.10-1.30$ & {$[55]$} & & \\
\hline \multicolumn{2}{|l|}{ Vegetables } & - & $0.08-0.93$ & $0.15-0.56$ & $1.27-3.7$ & [68] & & \\
\hline \multirow{2}{*}{\multicolumn{2}{|c|}{ Vegetables (Malaysia) }} & - & $0.03-0.09$ & $0.001-0.01$ & $1.59-5.20$ & {$[65]$} & & \\
\hline & Peninsular of Malaysia & $63.2-414.4$ & - & - & - & [41] & & \\
\hline
\end{tabular}




\section{Conclusion}

651 The heavy metal contents in borehole were significantly lower than the heavy metal

652 contents in surface water. Heavy metal contents in the borehole after PG organic

653 application were below the target value standard in the Malaysian Standard for Raw

654 Drinking Water Quality [33]. Heavy metal contents in soil in the plot treated with PG

655 organic were significantly lower or not significantly different compared to the heavy

656 metal contents in the control. All metal concentrations were below the target values

657 stipulated in the new Dutch list [32]. Heavy metal concentrations in the corn grain 658 were lower than the standards in the Malaysian Food Act [34] and Food Regulation

659 [35]. The analysis of the naturally occurring radionuclide concentrations in soil

660 samples indicated that the radioactivity concentrations of ${ }^{226} \mathrm{Ra},{ }^{228} \mathrm{Ra}$, and ${ }^{40} \mathrm{~K}$ in all

661 samples were much lower than their average concentrations in Malaysia's soil, as

662 reported by United Nations [48]. The determined radioactivity concentrations of

$663{ }^{226} \mathrm{Ra},{ }^{228} \mathrm{Ra}$ and ${ }^{40} \mathrm{~K}$ were also comparable with those of another study conducted in

664 Malaysia. The analysis of the natural radioactivity concentration in several plants also

665 showed that the results obtained in this study were comparable with those other

666 studies. The analysis of the groundwater indicated that no leaching of the

667 radionuclides from soil to groundwater occurred. In addition, the analysis of the 668 surface water (nearest river) suggested that no accumulation (discharge) of natural

669 radionuclided due to the application of PG organic occurred in the surface water. The

670 calculated $\mathrm{Ra}_{\mathrm{eq}}$ for soil was less than the $370 \mathrm{~Bq} \mathrm{~kg}^{-1}$ recommended limit of $\mathrm{R}_{\mathrm{eq}}$ in

671 soil. Based on these findings, it can be concluded that the application of PG organic

672 had no impact on the environment (in soil and plants) at the studied location. The 
673 biological accumulation coefficient (BAC), contamination factor (CF), I-geo index

674 (Igeo) and PLI showed that there was no accumulation of metals in grain, and no

675 contamination and no pollution occurred in borehole water and the BRIS soil that

676 received applications of PG organic. These data indicated that the use of PG organic

677 as a soil conditioner in BRIS soil is safe for the soil-plant-water.

678

679 Declarations

680 Acknowledgments

681 We would like to express our gratitude to Universiti Putra Malaysia as well as

682 Universiti Kebangsaan Malaysia for the technical support. A part of this research was

683 supported by Universiti Kebangsaan Malaysia under grant number GUP-2018-084.

684

685 Ethics approval and consent to participate

686 Not applicable.

687 Consent for publication

688 Not applicable.

689 Availability of data and material

690 All data generated or analyzed during this study are included in this published article.

691 Competing interests

692 The authors declare that they have no competing interests.

693 Funding

694 Not applicable. 


\section{Author's contributions}

696 MMH: Conceptualization, investigation, experimental analysis, data evaluation and

697 carrying out the experiment. PA: Writing manuscript and editing. ARS, IWMR and

698 IAF: carrying out the experiment. All authors read and approved the final manuscript.

\section{References}

700 1. Sahibin A, Shamshuddin J, Fauziah C, Radziah O, Razi IWM, Enio M (2019)

701 Impact of $\mathrm{Mg}$ rich synthetic gypsum application on the environment and palm

702 oil quality. Sci Total Environ 652: 573-582.

703 2. Duhne T (2014) Magnesium rich synthetic gypsum health and ecological 704 hazards and risk assessment. Golder Associates: Lynas cooperation, Sydney, $705 \quad$ Australia.

706 3. Centre EBT (2014) Analysis of hazardous characteristic of NUF sludge 707 samples. Environment \& Bioprocess Technology Centre: SIRIM Malaysia.

708 4. Torium P (2014) Digestion study of wáter leach purification (WLP) residue 709 for possibility of thorium extraction. Malaysian J Anal Sci 18 (1): 221-225.

710 5. Surach B (2016) Agricultural use for Lynas residue. 711 https://www.thesundaily.my/archive/2099215-KTARCH415877.

712 6. Toriman ME, Mokhtar M,Aziz NAA (2009) Analysis of the physical 713 characteristics of bris soil in Coastal Kuala Kemaman, Terengganu. Res J $714 \quad$ Earth Sci $1(1): 1-6$. 
715 7. Nafis AW (1981) Asas Sains Tanah. Dewan Bahasa dan Pustaka, Kuala 716 Lumpur.

717 8. Hanafiah MM, Adam JH, Gasim MB, Rahin SA, Muslim NE (2004) 718 Pengurusan dan Pemuliharaan Tanah Bris untuk Aktiviti Pertanian di Marang, 719 Terengganu. in: Norhayati Mohd Tahir, Nakisah Mat Amin and 720 Kamaruzzaman Yunus (eds). KUSTEM Third Annual Seminar on $721 \quad$ Sustainability Science and Management.

722 9. Muslim NE, Adam JH, Gasim MB, Rahin SA, Hanafiah MHM (2004) Sifat 723 dan Taburan Tanah Bris di Kemaman, Terengganu. in: Norhayati Mohd Tahir, 724 Nakisah Mat Amin and Kamaruzzaman Yunus (eds). KUSTEM Third Annual 725 Seminar on Sustainability Science and Management.

726 10. Wong P (1981) Beach changes on a monsoon coast, Peninsular Malaysia.

727 11. Shamsuddin J (1990) Sifat dan pengurusan tanah di Malaysia. Dewan Bahasa 728 dan Pustaka, Kuala Lumpur, Malaysia: 160-176.

729 12. Shamshuddin J (1981) Asas Sains Tanah. Dewan Bahasa dan Pustaka, Kuala $730 \quad$ Lumpur.

731 13. Ives W (1967) Reconnaissance Soil Survey of Southern Pahang. Kuala $732 \quad$ Lumpur: Malaysia Soil Survey Report No 4/ 1967.

733 14. Yaacob O, Jusoh S (1982) Sains Tanah. Kuala Lumpur: Dewan Bahasa dan $734 \quad$ Pustaka. 
735 15. Muchuweti M, Birkett J, Chinyanga E, Zvauya R, Scrimshaw MD, Lester J 736 (2006) Heavy metal content of vegetables irrigated with mixtures of 737 wastewater and sewage sludge in Zimbabwe: implications for human health. Agric Ecosyst Environ 112 (1): 41-48.

739 16. Arora M, Kiran B, Rani S, Rani A, Kaur B, Mittal N (2008) Heavy metal 740 accumulation in vegetables irrigated with water from different sources. Food Chem 111 (4): 811-815.

742 17. Chen L, Zhou S, Shi Y, Wang C, Li B, Li Y, Wu S (2018) Heavy metals in food crops, soil, and water in the Lihe River Watershed of the Taihu Region and their potential health risks when ingested. Sci Total Environ 615: 141-149.

745 18. Abdullah C (1988) Pengurusan Tanah Bris untuk Pengurusan Tanah Bris untuk Teknologi 4 (1): 13-19.

747 19. Shamsuddin J (1979) Tanah Bris di Pantai Timur. in: Mastika. 121-124.

748 20. Tchounwou PB, Yedjou CG, Patlolla AK, Sutton DJ (2012) Heavy metal 749 toxicity and the environment. in: Molecular, clinical and environmental toxicology, vol. Springer, 133-164.

751 21. Vongdala N, Tran H-D, Xuan T, Teschke R, Khanh T (2019) Heavy Metal Accumulation in Water, Soil, and Plants of Municipal Solid Waste Landfill in Vientiane, Laos. Int J Environ Res Public Health 16 (1): 22. 
754 22. Lutterotti L, Ceccato R, Dal Maschio R, Pagani E (1998) Quantitative analysis 755 of silicate glass in ceramic materials by the Rietveld method. in: Materials 756 Science Forum: Aedermannsdorf, Switzerland: Trans Tech Publications, 1984.

757 23. Bascomb A (1982) A study of the development of podzol profiles in Dovey 758 forest. Ph.D. Dissertation, University of Wales, Aberystwyth.

759 24. Walkeley A (1947) A critical examination of a rapid method for determination 760 of organic carbon in soils: effect of variation in digestion conditions and of 761 inorganic soil constituents. Soil Sci. 63: 251-257.

762 25. Murphy J, Riley JP (1962) A modified single solution method for the 763 determination of phosphate in natural waters. Anal Chim Acta 27: 31-36.

764 26. AOAC (1984) Methods of Analysis. 14th ed Official.

765 27. Association APH, Association AWW, Federation WPC, Federation WE 766 (2005) Standard methods for the examination of water and waste water.

767 28. USEPA (1996) Method 3050b: Acid digestion of siliceous and organically 768 based matrices. in: In: Test Methods for Evaluating Solid Waste, Physical/ 769 Chemical Methods, Office of Solid Waste and Emergency Response.

770 29. IAEA (1989) Measurement of Radionuclides in Food and the Environment. in: TSR 295.

30. Aznan FI, Muhamad SY, Amran AM, Redzuwan Y, Ismail B (2009) Radiological hazard of natural radionuclide in portland cement of peninsular malaysia. Sains Malays 38 (3): 407-411. 
775 31. Majid AA, Ismail AF, Yasir MS, Yahaya R, Bahari I (2013) Radiological dose 776 assessment of naturally occurring radioactive materials in concrete building 777 materials. J Radioanal Nuc Chem 297 (2): 277-284.

778 32. Target D (2000) Circular on target values and intervention values for soil 779 remediation. The new Dutch list, version February 4th.

780 33. $\mathrm{MOH}$ (2000) National Standard for Drinking Water Quality. Engineering of 781 Services Division, Ministry of Health Malaysia, Malaysia.

782 34. MALAYSIA LO (1983) FOOD ACT 1983. in: Act 281. 1-47.

783 35. MALAYSIA LO (1985) Food Regulations. 1-123.

784 36. Ghosh M, Singh S (2005) A comparative study of cadmium phytoextraction 785 by accumulator and weed species. Environ Pollut 133 (2): 365-371.

786 37. Muller G (1969) Index of geoaccumulation in sediments of the Rhine River. $787 \quad$ Geojournal 2: 108-118.

788 38. Hakanson L (1980) An ecological risk index for aquatic pollution control. A 789 sedimentological approach. Water Res 14 (8): 975-1001.

790 39. Soares H, Boaventura R, Machado A, Da Silva JE (1999) Sediments as 791 monitors of heavy metal contamination in the Ave river basin (Portugal): 792 multivariate analysis of data. Environ Pollut 105 (3): 311-323.

793 40. Tomlinson D, Wilson J, Harris C, Jeffrey D (1980) Problems in the 794 assessment of heavy-metal levels in estuaries and the formation of a pollution 795 index. Helgol Meeresunters 33 (1): 566. 
796 41. Almayahi B, Tajuddin A, Jaafar M (2014) Measurements of natural 797 radionuclides in human teeth and animal bones as markers of radiation 798 exposure from soil in the Northern Malaysian Peninsula. Radiat Phys Chem 799 97: 56-67.

800 42. Stranden E (1976) Some aspects on radioactivity of building materials. Phys 801 Norv 8 (3): 163-167.

802 43. Agency NE (1979) Exposure to radiation from the natural radioactivity in 803 building materials: report.

804 44. Balonov M, Barnett C, Belli M, Beresford N, Berkovsky V, Bossew P, Boyer 805 P, Brittain J, Calmon P, Carini F (2010) Handbook of parameter values for the 806 807 808 45. Meharg AA (eds) (2011) Trace Elements in Soils and Plants. United States of 809 America.

810 46. Khan MU, Ahmed M, Shaukat SS, Nazim K, Ali QM (2013) Effect of industrial waste on early growth and phytoremediation potential of Avicennia marina.(Forsk.) Vierh. Pak J Bot 45 (1): 17-27.

813 47. Harikumar P, Nasir U, Rahman MM (2009) Distribution of heavy metals in the core sediments of a tropical wetland system. International Journal of Environ Sci Technol 6 (2): 225-232. 
816 48. Radiation UNSCotEoA, Annex B (2000) Exposures from natural radiation $817 \quad$ sources. New york, United Nation.

818 49. Alzubaidi G, Hamid F, Abdul Rahman I (2016) Assessment of natural 819 radioactivity levels and radiation hazards in agricultural and virgin soil in the $820 \quad$ state of Kedah, north of Malaysia. Sci World J 2016.

821 50. Alias M, Hamzah Z, Saat A, Omar M, Tajuddin Z, Kadir WMWA, Solleh 822 MRM (2004) Level of naturally occurring radioactive material, K-40 in oil palm's cultivated soil. J Nuc Related Technol 1 (2): 1-11.

824 51. Alias M, Hamzah Z, Saat A, Omar M, Tajuddin Z (2005) Determination of 825 226Ra, 228Ra and 40K in soil from felda jengka-15 oil palm plantation. 826 Malaysian J Anal Sci 9 (1): 126-132.

827 52. Alsaffar MS, Jaafar MS, Kabir NA, Ahmad N (2015) Distribution of 226Ra, 828

830 53. Hamzah Z, Rahman SAA, Saat A (2011) Measurement of 226Ra, 228Ra and 831

833 54. Alnassar N, Jaafar M, Kabir N (2017) Determination of concentrations of 834 natural radionuclides in soils and water in non-cultivated sites in Seberang 835 Perai, Malaysia. IOSR J Appl Phys 9 (2): 27-35.

836 55. Asaduzzaman K, Khandaker M, Amin Y, Mahat R (2015) Uptake and 837 distribution of natural radioactivity in rice from soil in north and west part of 
838 peninsular malaysia for the estimation of ingestion dose to man. Ann Nucl $839 \quad$ Energy 76: 85-93.

840 56. Ismail NF, Ibrahim N (2016) Natural radioactivity in groundwater and soils in $841 \quad$ Johor Malaysia. ARPN J Eng Appl Sci 11 (18): 10935-1039.

842 57. Atwood DA (2013) Radionuclides in the Environment. West Sussex, United $843 \quad$ Kingdom.

844 58. Chakraborty SR, Azim R, Rahman AR, Sarker R (2013) Radioactivity 845 concentrations in soil and transfer factors of radionuclides from soil to grass 846 and plants in the Chittagong city of Bangladesh. J Phys Sci 24 (1): 95.

847 59. Abojassim AA, Hady HN, Mohammed ZB (2016) Natural radioactivity levels 848 in some vegetables and fruits commonly used in Najaf Governorate, Iraq. J $849 \quad$ Bioenerg Food Sci 3 (3): 113-123.

850 60. Priharti W, Samat SB (2016) Radiological risk assessment from the intake of 851 vegetables and Fruits in Malaysia. Malaysian J Anal Sci 20 (6): 1247-1253.

852 61. Olatunji MA, Uwatse OB, Khandaker MU, Amin Y, Faruq G (2014) 853 Radiological study on newly developed composite corn advance lines in $854 \quad$ Malaysia. Phys Scr 89 (12): 125002.

855 62. Greger M (2004) Uptake of nuclides by plants. Stockholm University. 856 Sweden, Technical Report TR-04-14. Available at. http://www.skb. se/upload.

857 63. Agency IAE (2013) Radiation protection and management of NORM residues 858 in the phosphate industry.

859 64. Radiation UNSCotEoA (1982) Ionizing radiation: sources and biological $860 \quad$ effects, United Nations Publication No. E. 
861 65. Solehah A, Yasir MS, Samat S (2016) Activity concentration, transfer factors 862 and resultant radiological risk of 226Ra, 232Th, and $40 \mathrm{~K}$ in soil and some 863 vegetables consumed in Selangor, Malaysia. in: AIP Conference Proceedings: $864 \quad$ AIP Publishing.

865 66. Carini F (2001) Uptake and distribution of natural radioactivity in wheat 866 plants from soil. Environ Radioact 52: 237-279.

867 67. Saeed M, Wahab N, Hossain I, Ahmed R, Abdullah H, Ramli A, Tahir BA 868 (2011) Measuring radioactivity level in various types of rice using hyper pure 869 germanium (HPGe) detector. Int J Phys Sci 6 (32): 7335-7340.

870 68. Gaffar S, Ferdous M, Begum A, Ullah S (2014) Transfer of natural 871 radionuclides from soil to plants in North Western parts of Dhaka. Malaysian J 872 Soil Sci 18: 61-74.

873 874 875 


\section{Figures}

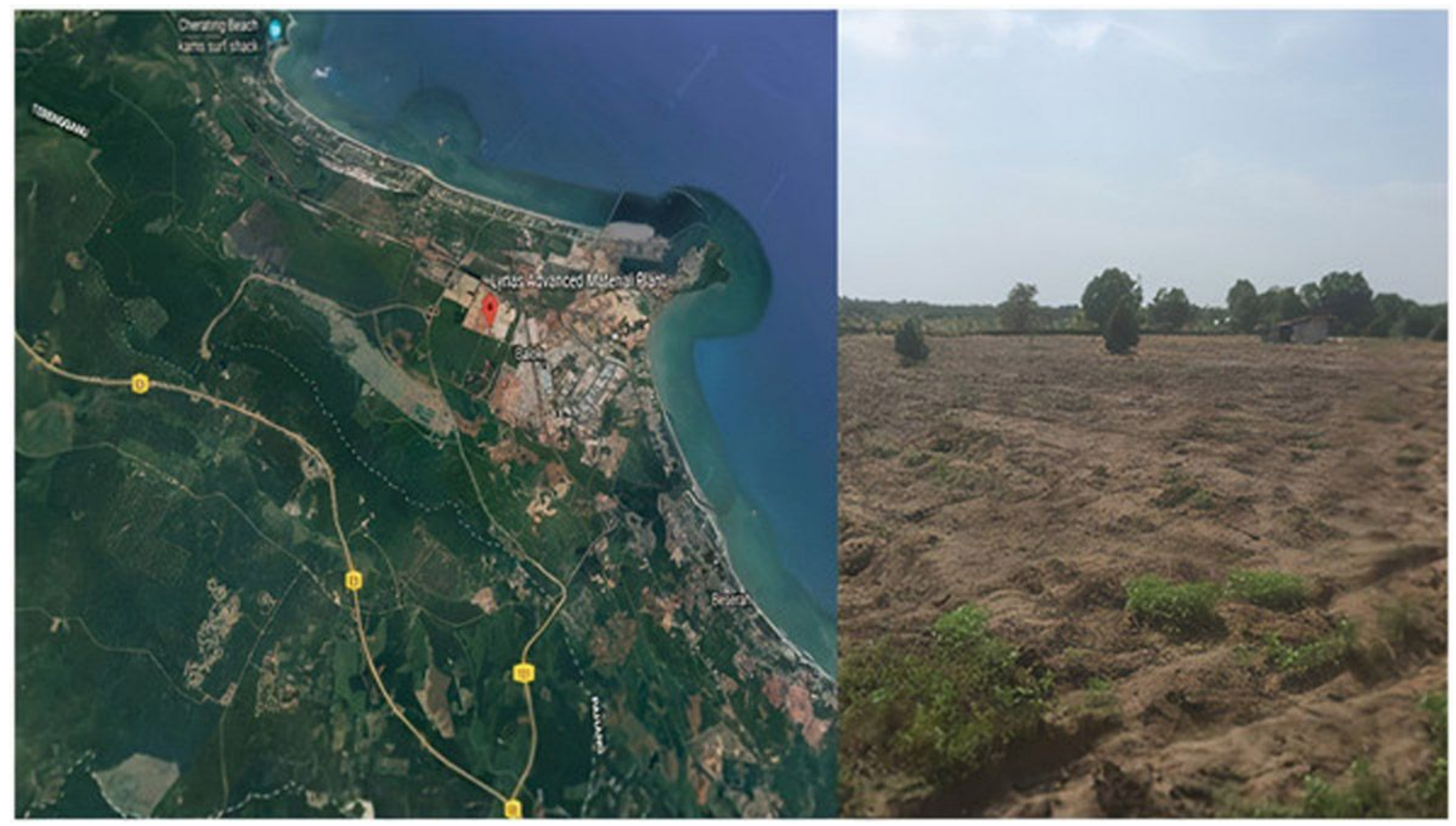

\section{Figure 1}

The location of the experimental site and the Lynas Advance Material Plant (LAMP). 

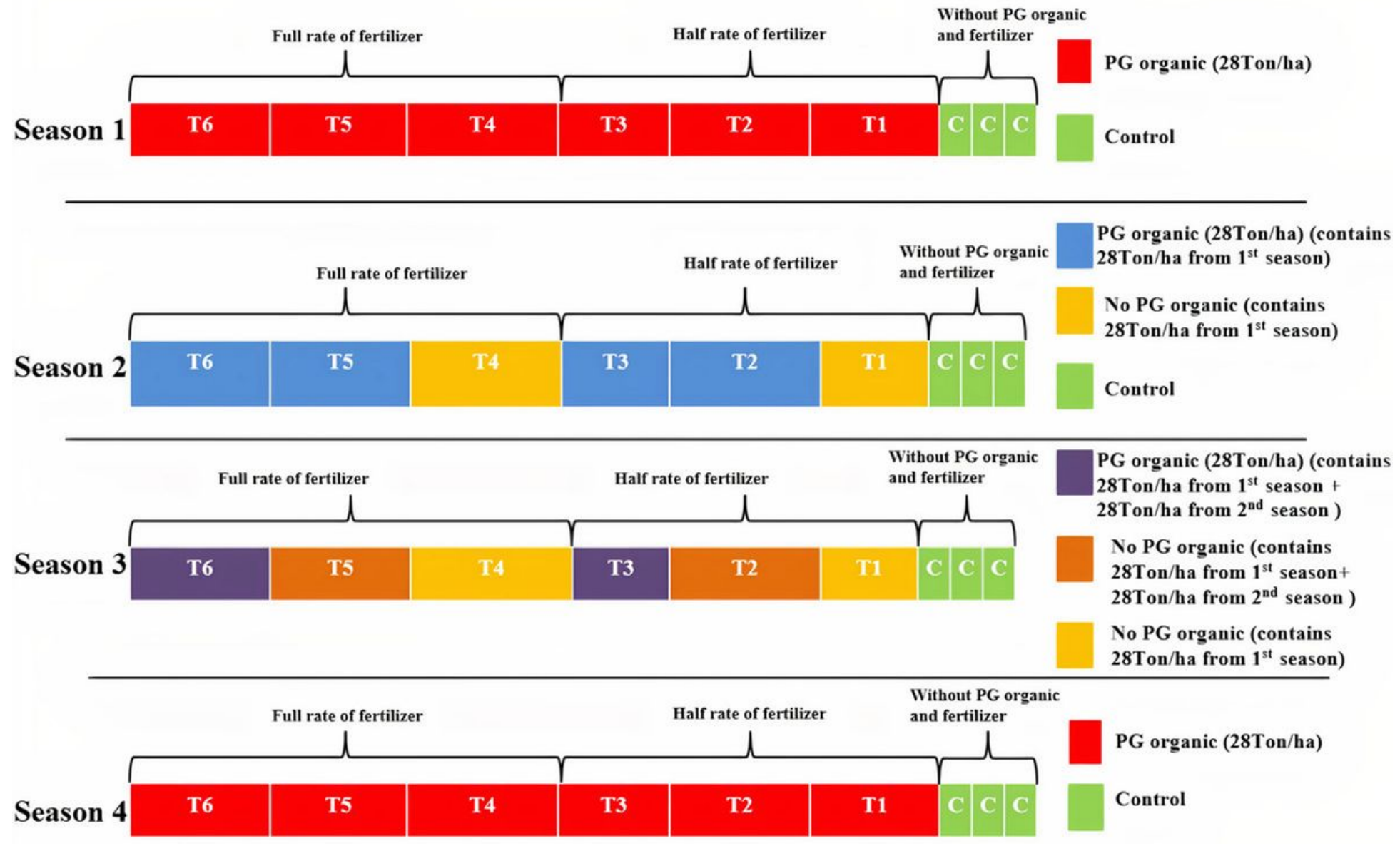

\section{Figure 2}

The sub-plots receiving the PG organic conditioner treatment for 3 cropping seasons for kenaf, maize, and guinea grass. Blue represents the sub-plot receiving the soil conditioner for each cropping season, and yellow represents the sub-plot receiving residual treatment. 


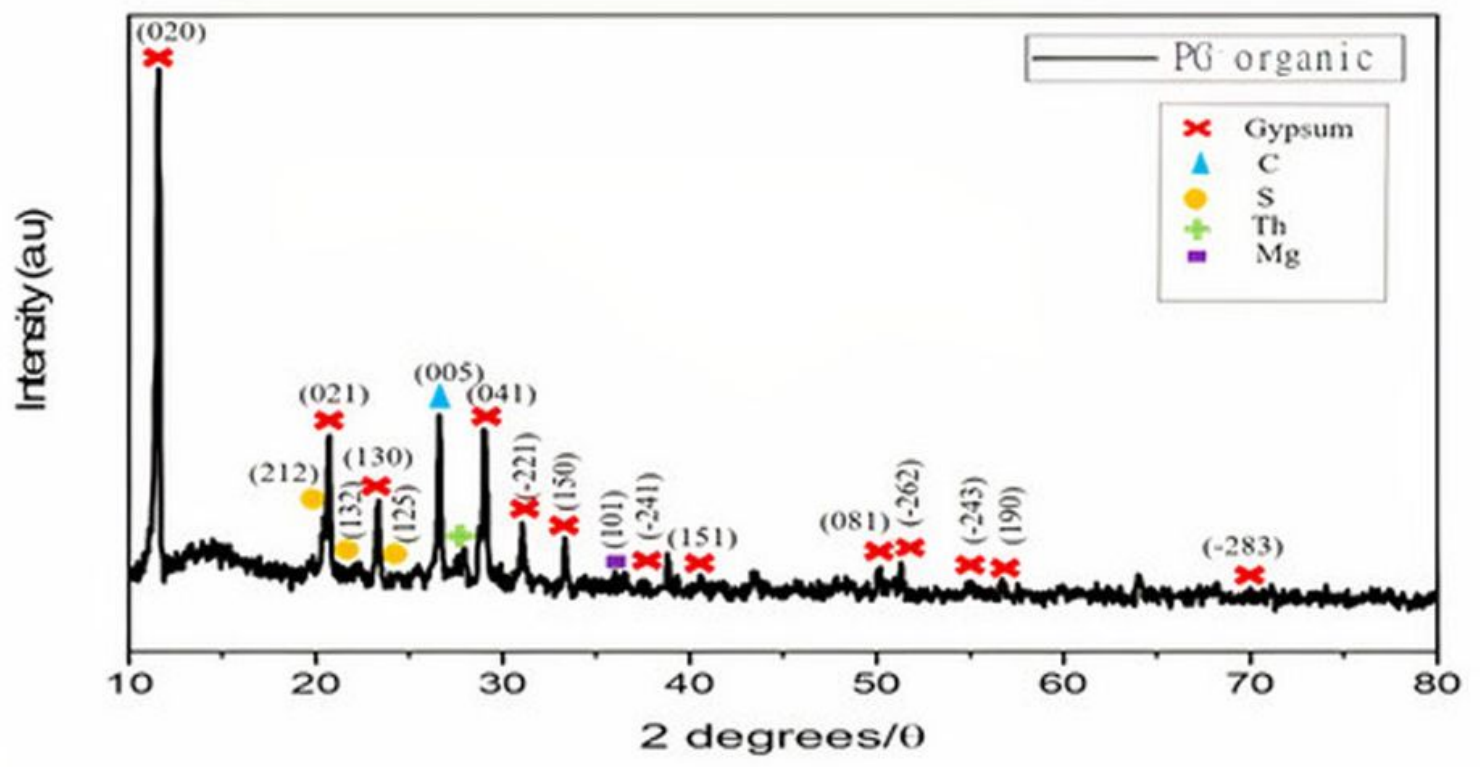

Figure 3

The XRD diffractogram of PG organic conditioner using PXRD method. 